\title{
Acid Rock Drainage Passive Remediation: Potential Use of Alkaline Clay, Optimal Mixing Ratio and Long-term Impacts
}

\author{
Fernando Plaza ${ }^{1}$, Yipei Wen ${ }^{1}$, Hanna Perone ${ }^{2}, \mathrm{Yi} \mathrm{Xu}^{1}$ and Xu Liang ${ }^{1 *}$ \\ ${ }^{1}$ Department of Civil and Environmental Engineering, University of Pittsburgh, \\ Pittsburgh, PA USA \\ ${ }^{2}$ Department of Chemistry, University of Pittsburgh, Pittsburgh, PA USA
}

\begin{abstract}
Acid rock drainage (ARD) is one of the most adverse environmental problems of the mining industry. Surface and ground water affected by this pollution are characterized by their acidity and the high content of sulfates and metals/metalloids.

In this study, alkaline clay (AC), an industrial waste with a high alkalinity, which is utilized in the alumina refining process, was used as the remediation material to inhibit pyrite oxidation in waste coal piles. Through a series of laboratory experiments (static and kinetic), complemented with field measurements and geochemical modeling, three important issues associated with this passive and sustainable ARD remediation method were investigated: 1) the potential use of alkaline clay as an ARD remediation material, 2) the adequate alkaline clay/coal refuse mixing ratio $(A C / C R)$ to ensure $\mathrm{pH}$ values close to neutral conditions, and, 3) the implications for long-term performance, in terms of the trends of the main parameters involved in this process such as $\mathrm{pH}$, concentrations of sulfate, iron and other dissolved contaminants. Both field measurements and the samples used for the experiments came from a local waste coal site.

Through the analysis of the field measurements and the outcome of the laboratory experiments, AC proved to be an effective remediation material for ARD. Compared to those found in mine tailings, the concentrations of contaminants such as iron, manganese or sulfate were significantly reduced with this remediation approach. Moreover, results suggest a reliable long-term stability of the remediation (i.e. neutral $\mathrm{pH}$ conditions are maintained), thus enhancing the generation of iron precipitates that could produce pyrite grain coating. These processes also made the amended layer less porous, thus increased water retention and hindered oxygen diffusion.
\end{abstract}

Keywords: mine waste, coal refuse, pyrite oxidation, dissolved metal removal, acidic neutralization

* Corresponding author, Email: xuliang@ pitt.edu, Phone: 412-624-9872

Address: 728 Benedum Hall, 3700 O'Hara St, Pittsburgh PA, 15261 


\section{INTRODUCTION}

The acid rock drainage (ARD) process associated with the mining industry constitutes one of the most serious types of water pollution in regions such as the Northern Appalachian Coalfield in the USA, where the mining activity has caused widespread degradation of water resources (Herlihy et al., 1990 and Cravotta III, 2008). Surface and ground water affected by this pollution are characterized by their acidity and high content of sulfates and metals/metalloids. The ARD process initiates when sulfide minerals, highly contained in mining wastes, oxidize through complex chemical reactions involving the combined action of oxygen (e.g. the oxidant) and water (e.g. the solvent). As pyrite is usually the sulfide mineral involved, this process is often referred as pyrite oxidation, which results in the production of sulfate and ferrous iron in addition to other byproducts such as elemental sulfur, polysulfide, hydrogen sulfide, ferric hydroxide, iron oxide or iron oxyhydroxide (Chandra et al., 2010).

Three main stoichiometric chemical reactions (Garrels et al., 1960 and Singer et al., 1970) are often used to describe aqueous pyrite $\left(\mathrm{FeS}_{2}\right)$ oxidation: 1) pyrite (e.g. the sulfide mineral) oxidizes and produces dissolved iron $\left(\mathrm{Fe}^{2+}\right)$, sulfate $\left(\mathrm{SO}_{4}{ }^{2-}\right)$ and hydrogen $\left(\mathrm{H}^{+}\right)$, that leads to the increase in the total dissolved solids and the acidity of the water, resulting in the decrease in $\mathrm{pH}, 2)$ in the presence of adequate oxygen $\left(\mathrm{O}_{2}\right)$ and hydrogen $\left(\mathrm{H}^{+}\right)$ concentrations, ferrous iron $\left(\mathrm{Fe}^{2+}\right)$ will oxidize into ferric iron $\left(\mathrm{Fe}^{3+}\right)$ and, 3) ferric iron may also oxidize pyrite into ferrous iron, sulfate and hydrogen. In addition, at low $\mathrm{pH}$ levels $(<$ 3.5), ferric iron precipitates into iron oxide hydroxide $\left(\mathrm{Fe}(\mathrm{OH})_{3}\right.$ solid $)$ and, simultaneously, produces hydrogen ions, thus resulting in lowering the $\mathrm{pH}$. 
Due to the severity of this environmental problem, several strategies have been developed to neutralize ARD generation. The most common approach is to divide the treatment into active and passive remediation processes (Johnson et al., 2005). Both strategies use biological and abiotic treatment.

Passive abiotic treatment emerges as a low-cost and effective strategy for ARD remediation. It does not require continuous operation and, moreover, it may harness nonconventional materials as neutralization agents (e.g. alkaline wastes). In other words, this treatment can operate in a more sustainable way (Younger et al., 2002). It has been found that, to some extent, passive treatment could have lower overall environmental impacts compared to active treatment technologies (Hengen et al., 2014). Hence, this study will focus on passive abiotic ARD remediation.

Several ARD passive treatment approaches have been developed in recent years, where the main concern is the search for an adequate alkaline remediation material. The choice of the alkaline material depends on many factors such as: neutralization potential, cost, production distance from the site, and supply according to the treatment demand (PerezLopez et al., 2011). For instance, an added value regarding passive remediation is the utilization of waste alkaline materials, thereby resulting in an environmentally friendly and sustainable solution.

Despite several previous studies of passive ARD remediation, there are still issues requiring improvement. For instance, the majority of the experimental strategies use complex systems for water addition (e.g. pumping), which sometimes generate artificial conditions that are difficult to replicate in-situ (e.g. limiting oxygen and water diffusion). Moreover, in most cases there is not a sufficient focus on the long-term impacts of the 
remediation technique nor is there an analysis of the optimal content of the reactive material to be applied in the field.

In this study, alkaline clay (AC), a highly basic nonhazardous industrial waste (according to the Resource Conservation and Recovery Act or RCRA) from the alumina refining process, was used as the remediation material to inhibit pyrite oxidation in waste coal piles. Through a series of static (i.e. batch and acid base accounting) and kinetic (i.e. flowthrough columns) experiments, complemented with field measurements and geochemical modeling, three important issues associated with this passive and sustainable ARD remediation method were investigated: 1) the potential use of $A C$ as an ARD remediation material, 2) the adequate alkaline clay / coal refuse mixing ratio $(\mathrm{AC} / \mathrm{CR})$ to ensure $\mathrm{pH}$ values close to neutral conditions, and, 3) the implications for long-term performance, in terms of the trends of the main parameters involved in this process such as $\mathrm{pH}$, concentrations of sulfate, ferrous iron and other metals.

\section{MATERIALS AND METHODS}

\subsection{Sample Collection, Material Characterization and Field Monitoring}

The coal refuse $(\mathrm{CR})$ samples were collected from a former coal mine in operation from 1925 to 1965, located in Mather, Greene County, Pennsylvania (USA). In 2009, a reclamation plan was started through the construction of four experimental plots, covering an approximate area of 1 hectare. Two of the test plots were constructed according to the following specifications:

- Plot 1: $100 \%$ CR (control plot).

- Plot 2: $90 \%$ CR with $10 \%$ AC mixed layer with a depth of 61 centimeters. 
An X-Ray Diffraction (XRD) test was used to obtain the mineral composition for both $\mathrm{CR}$ and AC (Table 12. At various points along the plots, instrumentation was installed to monitor the environmental impacts of the remediation, including lysimeters for collecting drainage water samples (at $61 \mathrm{~cm}$ and $91 \mathrm{~cm}$ ) that were later tested in the laboratory for $\mathrm{pH}$, sulfate, and metals/metalloids.

\subsection{Laboratory Experiments}

\subsubsection{Static Tests: Batch and Acid Base Accounting}

For the batch experiments, dry CR (samples were collected by 2012, in a different location than the experimental plots, inside the Mather site) and AC samples were passed through a \#16 sieve. A $30 \mathrm{~g}$ sample was packed into a $50 \mathrm{~mL}$ beaker. Samples were moistened using deionized water and kept at room temperature $\left(25^{\circ} \mathrm{C}\right)$ for $0-7$ days. The focus of the batch experiments was aimed at investigating the effect of the following factors:

- $\mathrm{AC}$ content or mixing ratio with respect to coal refuse (from $0 \% / 100 \%$ to $60 \% / 40 \%$ )

- Water content, in order to reflect the effect of soil moisture in the column experiment. The chosen water amounts were $0,5,10$ and $15 \mathrm{~mL}$

- Reaction time, in order to reflect the effect of water flushing frequency in the subsequent column experiment. The chosen reaction times were 1, 3 and 7 days

Once the intended reaction time was reached, $90 \mathrm{~mL}$ of deionized water was mixed with the sample and stirred for 15 minutes. Then, the supernatant was extracted and filtered with a $0.45 \mu \mathrm{m}$ membrane. The $\mathrm{pH}$ of the filtered liquid was measured immediately. As a control, $30 \mathrm{~g}$ samples with 0 day reaction time and no water addition were prepared. The remaining treatment procedure for the control batch is the same as the one described above. 
The acid base accounting test, based on the methodology developed by Sobek et al. (1978), was performed to establish a balance between the acid-producing and acidconsuming components in the mixture. The main assumptions of this method are: a) pyrite is oxidized by oxygen, b) the acid production potential is based on the total sulfur content $(\% \mathrm{~S}), \mathrm{c}) 1$ mole of $\mathrm{S}$ produces 2 moles of acid $\left(\mathrm{H}^{+}\right)$, which is neutralized by 1 mole of calcium carbonate $\left(\mathrm{CaCO}_{3}\right)$, thus requiring $31.25 \mathrm{~kg}$ of $\mathrm{CaCO} 3$ per ton of material to neutralize $1 \% \mathrm{~S}$. The $\% \mathrm{~S}$ was calculated from the XRD analysis and the acid potential (AP) was calculated using the above-mentioned relationship.

Samples of $A C$ and $\mathrm{CR}$ were acidified with hydrochloric acid $(\mathrm{HCl})$ and then titrated with sodium hydroxide $(\mathrm{NaOH})$ in order to determine the acid consumption. Later, the acid neutralization potential (NP) in terms of $\mathrm{Kg} \mathrm{CaCO}_{3} /$ ton was calculated for both $\mathrm{AC}$ and $\mathrm{CR}$.

For both static tests, the sample analysis was triplicated and the results presented in this study correspond to the average value of each described case.

\subsubsection{Kinetic Tests: Flow-Through Columns}

Four column experiments were set up to evaluate ARD remediation. The columns were built using polycarbonate tubes with an internal diameter of $10 \mathrm{~cm}$. The columns were filled with uncompacted CR (samples were collected by 2013) and AC, passing through a \#4 sieve, to a height of $15 \mathrm{~cm}$. A net containing $4 \mathrm{~mm}$ diameter glass beads was installed to prevent clogging at the bottom outlet of each column.

The column sides were covered to prevent light from reaching the mixture (Figure 1a). Deionized water $(\mathrm{pH}=7)$ was added periodically (i.e. slowly to avoid water accumulation at the surface) at the top of the columns to simulate rainfall. The water was allowed to drain freely through the column. At the bottom, water was collected through a rubber hose. 
An acceptable amount of fine particles were lost through the beads at the outlet. For all of the columns, except column 3, $200 \mathrm{~mL}$ of water were added per week (equivalent to approximately $1,300 \mathrm{~mm}$ per year), which is similar to the average annual precipitation in southwestern Pennsylvania (www.usclimatedata.com). Only $100 \mathrm{~mL}$ of water was added to column 3 to simulate drier environmental conditions. At the beginning of the experiments, the water retention time varied from around 1 to 3 hours. Saturated conditions were maintained at the bottom of the columns, which inhibited oxygen diffusion through the outlet.

The mixture in column 1 consisted of $10 \%$ AC and $90 \%$ CR. Column 2 used the same mixture as column 1 except that the solid sample used to pack it was ground and, therefore, featured a smaller grain size in general. This column was designed for testing the effect of the particle size. Column 3 also used the same mixture as column 1 but varied the amount of water added. Column 4 served as the control column (100\% CR). Figure $1 b$ shows a schematic column design. The conditions of columns 1 and 4 were duplicated to provide a comparative analysis of the kinetic tests for the amended and non-amended scenarios.

The collected liquid sample was filtered using a $0.45 \mu \mathrm{m}$ MF-Type (mixed cellulose esters) filter membrane and the $\mathrm{pH}$ was measured immediately. The sample was then subject to chemical composition analysis using an ICP-MS:Perkin Elmer NeXION 300X inductively coupled plasma mass spectrometer (EPA Method 200.8) and an IC:DIONEX ICS-1100 (EPA Method 300.0) to measure the concentration of dissolved metals/metalloids and sulfate, respectively.

\subsection{Geochemical Modeling: PHREEQC}


In recent years, PHREEQC (Parkhurst et al., 1999 and 2013) has become a valuable tool for simulating geochemical processes in a variety of environmental conditions. Sahoo et al. (2013) utilized PHREEQC to calculate the saturation indices (SI) of various $\mathrm{Fe}$ oxyhydroxides (HFO) and calcium carbonates phases from the leachates of columns experiments. Appelo et al. (1998) modeled in PHREEQC the chemical composition of a column effluent. Motalebi et al. (2012) explored the effect that some input parameters of PHREEQC (e.g. flow rate, initial $\mathrm{pH}$, grain size distribution) have on the transport of dissolved metals such as $\mathrm{Mn}, \mathrm{Ni}$ and $\mathrm{Cd}$ in a mine tailing.

In this study, PHREEQC is used to provide important information about the dissolution/precipitation processes through the interactions between the aqueous and minerals phases by simulating the scenarios described by the column experiments. In addition, PHREEQC is utilized to predict the long-term behavior of the system, beyond the experimental time (i.e. $\approx 600$ days). The ARD simulations (for amended and non-amended scenarios) using the PHREEQC model were made under the assumption that pyrite oxidation was produced by dissolved oxygen (DO) or by ferrous iron $\left(\mathrm{Fe}^{3+}\right)$ as the oxidants (Williamson and Rimstidt, 1994).

\section{RESULTS AND DISCUSSION}

\subsection{Field Measurements}

Figure 2 shows data retrieved from the Mather samples over a five-year period (i.e. 2009 2014) for the non-amended plot 1 (i.e. $100 \%$ CR) and plot 2 with a $61 \mathrm{~cm}$ amended layer (i.e. $90 \% \mathrm{CR}+10 \% \mathrm{AC}$ ). It is worth mentioning that in the spring of 2011 , plot 1 was covered with the same amended layer as plot 2. 
Regarding $\mathrm{pH}$ levels, results showed a significant increase in $\mathrm{pH}$ in plot 2 . At $61 \mathrm{~cm}$, the $\mathrm{pH}$ varied approximately from 3 to 7 . In the same plot, but underneath the amended layer (i.e. $91 \mathrm{~cm}$ ) the $\mathrm{pH}$ was acidic during the first two years, ranging from 2 to 3 . However, near the end of the five-year period, the $\mathrm{pH}$ was almost neutral (i.e. 6.37). As expected, the $\mathrm{pH}$ in the non-amended plot 1 is acidic during the entire study period. However, after the amendment of plot 1 in early 2011 , the $\mathrm{pH}$ increases to nearly 4 .

A general decreasing trend in Fe concentrations can be seen in Figure 2, even in the nonamended plot 1 . One of the possible reasons for the decreasing concentration was that $\mathrm{Fe}$ tends to precipitate, therefore, its concentration is limited in aqueous solution. In the nonamended plot 1, the initial Fe data in 2009 had a wide range, from 500 to $7,000 \mathrm{mg} / \mathrm{L}$. Fe was usually higher at $91 \mathrm{~cm}$ than at $61 \mathrm{~cm}$ depth. Data from 2011, following the amendment of plot 1 , yielded much lower Fe concentrations, from around 10 to $20 \mathrm{mg} / \mathrm{L}$. In the case of the amended plot 2 , the initial results at $61 \mathrm{~cm}$ showed concentrations less than $60 \mathrm{mg} / \mathrm{L}$ and the results from June 2014 showed concentrations less than $1 \mathrm{mg} / \mathrm{L}$. In the amended plot 2, at $91 \mathrm{~cm}$ (i.e. beneath the amended layer), the results showed a high influence of the amended layer (i.e. Fe concentrations reduced to $1.41 \mathrm{mg} / \mathrm{L}$ by the end of the study period), which is likely due to the infiltration of high $\mathrm{pH}$ water from the overlying amended layer.

Figure 2 shows Al following a similar decreasing trend as Fe. The amended layer in plot 2 had initial concentrations of $\mathrm{Al}$ of around $150 \mathrm{mg} / \mathrm{L}$ and, by 2014, they were less than 0.1 $\mathrm{mg} / \mathrm{L}$. Below the amended layer in plot 2 (i.e. at $91 \mathrm{~cm}$ ), Al decreased from approximately 800 to $0.07 \mathrm{mg} / \mathrm{L}$, in the same period of time. In the non-amended plot 1 , Al concentrations were higher, ranging from around 1,500 to $200 \mathrm{mg} / \mathrm{L}$, from 2009 to 2010 . 
Sulfate $\left(\mathrm{SO}_{4}\right)$ concentrations in Mather were mostly within the expected range. Sulfate is a major contaminant produced by the pyrite oxidation. Field measurements were made in 2010 and 2011. In the amended plot 2, at $61 \mathrm{~cm}$ and $91 \mathrm{~cm}$, sulfate ranged approximately from 1,700 to $2,200 \mathrm{mg} / \mathrm{L}$. In the non-amended plot 1 , sulfate varied from around 4,000 to $6,000 \mathrm{mg} / \mathrm{L}$. However, following the amendment of plot 1 in 2011 , there was some reduction in sulfate concentrations to $1,800 \mathrm{mg} / \mathrm{L}$ within the amended zone (i.e. $61 \mathrm{~cm}$ ) and to $2,400 \mathrm{mg} / \mathrm{L}$ below the amended zone (i.e. $91 \mathrm{~cm}$ ), respectively.

In general, results showed that the chemical concentrations in the Mather plots were highly representative of coal pile mine drainage. It was also shown that the use of $A C$ was beneficial to remediate the acid drainage in the coal waste at least during the five years of measurements. In the amended plot 2, there was a clear indication of dissolved metal removal and a $\mathrm{pH}$ increase towards neutral levels. Moreover, it was shown that despite plot 2 only having a $61 \mathrm{~cm}$ amended layer, there was evidence that this amended layer was beneficial to the non-amended layer below at the depth of $91 \mathrm{~cm}$ (i.e. lower levels of dissolved metals and sulfate than in the non-amended plot 1).

\subsection{Static Tests}

The $\mathrm{pH}$ values in the batch experiments are influenced by the $\mathrm{AC} / \mathrm{CR}$ ratio and moisture content (Figure 3a). It was noticeable that higher moisture content produced higher $\mathrm{pH}$ values. One possible reason could be lower diffusion rates due to higher saturated soil conditions. Another possibility may be due to a weathering effect (e.g. neutralization reactions), which would produce more alkaline substances available to react (Dold, 2014). Alternatively, due to the fact that the AC content is several times lower than the $C R$ and allowing the possibility that $\mathrm{AC}$ particles are not homogeneously distributed throughout the 
mix, additional water is likely responsible for increasing reaction between the AC particles and the $\mathrm{CR}$, which would explain the increase in the alkalinity during the short duration of the batch experiments. An experiment was designed to test the reaction time for various AC contents and, to initiate the reaction, $5 \mathrm{~mL}$ water were added.

It was observed that the $\mathrm{pH}$ for the batch reaction experiments for the control group was lower than almost every other sample tested (Figure 3b). This was expected because the absence of initial soil moisture resulted in less dissolved alkalinity. Regarding the AC content, in all three cases the trend was similar. It was also noticed in Figure $3 b$ that for $5 \%$ or less $\mathrm{AC}$ content, the $\mathrm{pH}$ was 4 or lower, which suggests that the $\mathrm{pH}$ in the leachate was primarily controlled by pyrite oxidation, both by oxygen and ferrous iron. For $8 \%$ AC, the $\mathrm{pH}$ was around $4-4.5$, which is still close to the threshold where ferrous iron can oxidize pyrite. Therefore, it would appear that the optimal AC content should be higher than $8 \%$. On the other hand, at $16 \% \mathrm{AC}$, the $\mathrm{pH}$ was higher than 6 , which is within the range of un-affected natural waters around the study area (Chaplin et al., 2007,_Sams et al., 2000_ and Williams et al., 1990).

It is necessary to emphasize that these batch experiments were intended to replicate the initial conditions of the remediation, at the time of the first rainfall, right after the $A C$ is mixed with the $\mathrm{CR}$ in the field. Therefore, these initial $\mathrm{pH}$ measurements were expected to be less than subsequent values as the pyrite oxidation rates may be initially faster than the generation of alkalinity (Huminicki et al., 2009).

In order to have a narrower range from where to choose an optimal mixing ratio, Figure $3 c$ provides more clarification. This figure shows the $\mathrm{pH}$ results for various $\mathrm{AC}$ contents for three reaction times: 0,3 and 7 days. It is clear that, for $5 \% \mathrm{AC}$ or less, the $\mathrm{pH}$ did not 
seem to be influenced by the reaction time. In this case, it is probable that the AC content was not enough to rapidly increase the neutralization capacity. At $8 \% \mathrm{AC}$, the reaction time seemed to have some influence; however, the $\mathrm{pH}$ remained lower than 5 . Although the $\mathrm{pH}$ can eventually reach neutral levels at $8 \% A C$, there is some uncertainty regarding the long-term stability of this mixing ratio. In other words, for $8 \% \mathrm{AC}$, it is uncertain if the $\mathrm{pH}$ is going to be on the neutral side and how long it will remain this way until the alkalinity is consumed.

The $\mathrm{pH}$ for the $10 \% \mathrm{AC}$ mixture showed a more significant influence regarding the reaction time, increasing from 4.9 to 5.8 . Similarly, the $\mathrm{pH}$ in the $20 \% \mathrm{AC}$ and $30 \% \mathrm{AC}$ mixtures also was influenced by the reaction time. In these two cases the $A C$ content was relatively high; therefore, it took time for the alkalinity to reach a stable dissolving rate (i.e. a longer "activation" time). It is noticeable that, in the case of the 7-day reaction time, increasing the AC from $8 \%$ to $10 \%$, increased the magnitude of the $\mathrm{pH}$ by 1.3 . However, increasing the AC from $10 \%$ to $20 \%$, only increased the magnitude of the $\mathrm{pH}$ by 1 . This suggests that there might be an $A C$ content within the range of $10 \%-20 \%$ whereby increasing the $A C$ content does not necessarily improve the remediation in terms of the $\mathrm{pH}$ value.

In summary, at the lower limit, it is clear that the optimal AC content should be higher than $8 \%$. The upper limit slightly more complex to define. Our analysis might indicate that the optimal AC content should be less than $14 \%$. In addition, considering that it is our intent to determine the least $A C$ content possible that has an effective performance, $10 \% A C$ seems to be a reasonable assumption to be close to optimal conditions.

Figure 4 shows the results from the acid base accounting test and its interpretation. It is necessary to be aware of the limitations of this methodology in order to have a proper 
interpretation of the results, as under real field conditions, not all $S$ will produce acid, neither will all the alkaline material be available to react and neutralize the acidity.

There are two main criteria to interpret the results. The first criterion is based on the Net Neutralization Potential (NNP), which is the difference between the Neutralization Potential $(\mathrm{NP})$ and the Acid Potential (AP) (i.e. NNP = NP - AP) (Brady et al., 1992). NNP values in the range of -20 to $20 \mathrm{~g} \mathrm{CaCO} 3 / \mathrm{kg}$ are generally considered to be uncertain. NNP values less than -20 are typically taken to indicate acid producing potential while NNP values greater than 20 are usually identified with little potential to produce net acidity. Based on these criteria, Figure $4 a_{-}$shows that a minimum of $6 \% \mathrm{AC}$ is required to be in the range of limited potential to produce net acidity (i.e. NPP $\geq 20 \mathrm{~g} \mathrm{CaCo3} / \mathrm{kg}$ ). Mixed samples of AC between $1 \%$ and $6 \%$ are assumed to be in the uncertainty range. Samples with less than $1 \%$ AC have acid producing potential.

The second criterion is based on the Neutralization Potential Ratio (NPR $=$ NP/AP) (Price et al., 1997). The results in Figure $4 b$ show that samples with $A C$ between $0 \%$ and $3.5 \%$ are likely to generate ARD. Samples with AC between $3.5 \%$ and $9.5 \%$ are less likely to produce ARD. With $9.5 \%$ and $20 \%$ of AC content, there is no potential for ARD generation, while for samples with more than $20 \%$ AC, it is assumed with more certainty that there will be no ARD.

Based on these results, our assumption is strengthened that a minimum of $10 \% A C$ is required for long-term remediation purposes. Specifically, $10 \%$ AC is assumed to be the minimum amount of remediation material that could guarantee that sufficient alkalinity is provided to neutralize the acidity in the long term, even beyond the duration of the field 
measurements and the kinetic experiments (i.e. > 5 years). Therefore, a 10\% AC mixture will be adopted for the amended scenario of the kinetic tests (i.e., flow-through columns).

\subsection{Column Experiments}

\subsection{1. $\mathrm{pH}$}

Figure $5 \mathrm{a}$ shows the leachate $\mathrm{pH}$ from the columns described in Section 2.2.2. The average $\mathrm{pH}$ for columns 1 and 2, during the experiment was 7.59 and 7.83 , respectively. After a 600-day period, there was no indication of a pH decrease. It was noticeable that the $\mathrm{pH}$ in column 2 was slightly higher than in column 1 . This is likely due to the fact that column 2 had smaller particles (i.e., samples were ground before sieved), which made the mixture more homogeneous, and also, there is a higher surface contact between the water and the AC particles. However, the smaller particle size in column 2 did not produce a significant difference compared to column 1.

As previously mentioned, water addition frequency was $100 \mathrm{~mL} /$ week in column 3, which was assumed to be close to the moisture conditions in the field during the dry season. The leachate from column 3 took around two weeks to reach a neutral $\mathrm{pH}$, after which the $\mathrm{pH}$ values remained mostly above 7.5 . This column was neglected after approximately 200 days, as enough data were collected to note that reducing the water by half did not significantly change the $\mathrm{pH}$ compared to columns 1 and 2 .

In all these three columns it was evident that the increase in $\mathrm{pH}$ conditions was due to the addition of the alkaline material (i.e., AC). As a consequence, these conditions should reduce the proliferation of bacteria (i.e., thiobacillus ferroxidans), increase the metal adsorption and enhance the precipitation of HFO (Doye et al., 2003). These hydrous oxides of Fe (III) are fundamental in the transport and attenuation of trace metals via 
adsorption (Webster et al., 1998). In addition, due to the low solubility of these Fe-oxide phases under alkaline conditions, they can eventually encapsulate the sulfide mineral grain (e.g. pyrite), and lower the amount of mineral surface in contact with the oxidants, thus inhibiting the oxidation process until a state is reached, where the coating's effectiveness causes the acid generation to be less than the alkalinity of the ground water (Huminicki et al., 2009). Additionally, higher water retention in column 2 (i.e. fine particles) could play an important role for the coating of pyrite, as hydrodynamic conditions are important in the early stages of the coating development, where higher flow rates might remove $\mathrm{Fe}$ (II) and HFO before they can react and attach to the pyrite surface (Huminicki et al., 2009).

After 350 days, the $\mathrm{pH}$ in column 4 (i.e., control column) is within the range of $2.5-3$. At $\mathrm{pH}<3.5$, the solubility of HFO increases and pyrite oxidation by Fe (III) is faster than oxidation by dissolved oxygen (Williamson et al., 2006). Moreover, low pH conditions favor the growth of acidophilic bacteria (i.e., thiobacillus ferroxidans) that oxidize aqueous $\mathrm{Fe}$ (II) to $\mathrm{Fe}(\mathrm{III})$ (Doye et al., 2003). Finally, low pH inhibits precipitation and sorption reactions. Consequently, metals such as $\mathrm{Al}, \mathrm{Cu}, \mathrm{Mn}$ and $\mathrm{Zn}$ are likely to experience a conservative transport (Runkel et al., 2012).

\subsubsection{Sulfate}

In ARD chemistry, sulfate is usually seen as an indicator of sulfide mineral oxidation. Even without the contribution of dissolved oxygen, pyrite oxidation by $\mathrm{Fe}(\mathrm{III})$ produces sulfate (Doye et al., 2003). Moreover, sulfate is also controlled by mineral solubility, as it is associated with several mineral phases that are present in mine tailings, among which are jarosite $\left(\mathrm{KFe}_{3}(\mathrm{OH})_{6}\left(\mathrm{SO}_{4}\right)_{2}\right)$ and gypsum $\left(\mathrm{CaSO}_{4} 2 \mathrm{H}_{2} \mathrm{O}\right)$. Secondary sulfate minerals 
associated with ARD include Fe and Al-hydroxysulfate minerals (Hammarstrom et al., 2005).

Figure $5 b$ shows sulfate $\left(\mathrm{SO}_{4}\right)$ concentrations obtained from the columns' leachates. It is noticeable that, while the orders of magnitude are different, a similar trend is present in the sulfate concentrations for all four columns, characterized by an early steep decrease followed by an apparent plateau.

Column 1 had an average sulfate concentration of $1,872 \mathrm{mg} / \mathrm{L}$ during the first 100 days, after which the average plateaued around $1,481 \mathrm{mg} / \mathrm{L}$. Column 2 had an average sulfate concentration of $2,865 \mathrm{mg} / \mathrm{L}$ during the first 100 days, after which the average plateaued $1,490 \mathrm{mg} / \mathrm{L}$. Once again the particle size has no significant impact (i.e. column 2 results compared to column 1). It appears that the neutralization potential of the AC has a higher control compared to the other possible factors that might enhance the remediation process (e.g., higher water retention, less oxygen diffusion and more AC surface contact due to finer particles).

In column 4, the non-amended scenario, sulfate experienced a very steep decrease during the first 100 days, dropping from an initial $22,000 \mathrm{mg} / \mathrm{L}$ to approximately $6,000 \mathrm{mg} / \mathrm{L}$. This might indicate an initial high dissolution of sulfate minerals. After that, the sulfate continued to drop for another 50 days (i.e., from 6,000 to $2,000 \mathrm{mg} / \mathrm{L}$ ). From that point onward, the sulfate concentration stabilized at around $2,000 \mathrm{mg} / \mathrm{L}$ (i.e., at about day 200) for approximately 100 days and, then continued to gradually decrease until around 1,800 $\mathrm{mg} / \mathrm{L}$ at day 350 .

\subsubsection{Dissolved metals/metalloids}


Drainage water quality in reactive and remediated mine tailings is highly influenced by factors like water saturation level, particle size distribution and soil permeability, but may also be influenced by the mineral composition of the soil, which in turn controls the distribution of metals.

Figure 6 shows concentrations for the most important metals dissolved in the leachate for the amended and non-amended scenarios (Columns 1 and 4, respectively). Average Fe concentration in column 1 was $2.85 \mathrm{mg} / \mathrm{L}$ (range 2.13 to $3.77 \mathrm{mg} / \mathrm{L}$ ). Under alkaline $\mathrm{pH}$ conditions when pyrite is being oxidized, the released Fe rapidly precipitates as HFO phases such as ferrihydrite and goethite (Yee et al., 2006). Considering the data length (i.e. 450 days), it seemed that the Fe concentrations in column 1 were controlled by the Fe mineral solubility. Eventually, it is expected that the Fe concentrations would decrease. As an evidence, actual field measurements from the Mather site show a decrease in Fe concentration (Figure 2).

Ca concentrations in the amended scenario showed two clear trends. The first was characterized by a relatively stable increase during the first 180 days, where the concentration of $\mathrm{Ca}$ is generally within the range of $300-600 \mathrm{mg} / \mathrm{L}$. The second trend is where the $\mathrm{Ca}$ concentration increases from 500 to $700 \mathrm{mg} / \mathrm{L}$. This relatively high concentration of $\mathrm{Ca}$ could be an indication of ARD neutralization by the dissolution of $\mathrm{Ca}$ carbonates, such as calcite $\left(\mathrm{CaCO}_{3}\right)$, due to the alkaline additive, thus releasing $\mathrm{Ca}$. Usually, calcite is identified with acidic neutralization, enabling various metal removal mechanisms (Sun et al., 2013). However, high dissolution rates of Ca minerals could also occur in active mine tailings (e.g., CR). 
Mn showed a decreasing trend in the amended scenario. In mine tailings, $\mathrm{Mn}$ is usually produced by the dissolution of ankeritic dolomite contained in rocks (Banks, 2006). In column $1, \mathrm{Mn}$ dropped from around 0.9 to $0.4 \mathrm{mg} / \mathrm{L}$ during the first 230 days, after that, it stabilized around $0.2 \mathrm{mg} / \mathrm{L}$, being 0.16 the lowest value. At neutral $\mathrm{pH}$ values, precipitation of Mn phases occurs via bacterial mediation (PlumLee et al., 1999).

The Mg concentrations also showed a decreasing trend in the amended scenario, from the range $300-100 \mathrm{mg} / \mathrm{L}$ to $8-6 \mathrm{mg} / \mathrm{L}$, a relatively low concentration, which might indicate the precipitation of $\mathrm{Mg}$ carbonates (e.g., based on the PHREEQC modeling, the SI of dolomite was found to be in the range of $3.52-3.11$ ). Likewise, Na concentrations showed a dramatic decreasing trend, from 160 to approximately $10 \mathrm{mg} / \mathrm{L}$, which might be an indication of flushing out of brines and $\mathrm{Na}$ minerals initially present at the $\mathrm{CR}$ waste piles and/or the alkaline remediation material (e.g., sodalite $\left.\left(\mathrm{Na}_{8}\left(\mathrm{Al}_{6} \mathrm{Si}_{6} \mathrm{O}_{24}\right) \mathrm{Cl}_{12}\right)\right)$. Decreasing concentrations of $\mathrm{K}$ (i.e. from 12 to $2 \mathrm{mg} / \mathrm{L}$, approximately) might also be related to the flushing of brines. In the amended column, $\mathrm{Zn}$ had a very stable trend within the range of $0.5-2.5 \mathrm{mg} / \mathrm{L}$, with an average concentration of 1.42 . $\mathrm{Zn}$ is absorbed on Fe (II) oxides and hydroxides at moderately acidic and neutral pH conditions (Sracek et al., 2009).

Other important metals that characterize ARD such as Al and Co, were mostly below the detection limits in the amended scenario. When detected, Al varied from 0.001 to 0.07 $\mathrm{mg} / \mathrm{L}$. One of the main reasons for the low Al concentrations in the amended columns is that, at a close to neutral $\mathrm{pH}, \mathrm{Al}$ is limited by the precipitation of Al hydroxides (Nordstrom et al., 1999). Cu showed an oscillatory behavior within the range of 0.02 to $0.10 \mathrm{mg} / \mathrm{L}$, with an approximate average of $0.04 \mathrm{mg} / \mathrm{L}$. This low $\mathrm{Cu}$ concentration might be due to the fact that $\mathrm{Cu}$ hydroxide precipitates at $\mathrm{pH}>5.3 \mathrm{Cu}$ is strongly adsorbed onto $\mathrm{HFO}$ and other oxide phases (Britton, 1955). Other important dissolved metals detected at relatively low 
concentrations were $\mathrm{Ni}$ and $\mathrm{Cr}$, with average concentrations of 0.036 and $0.039 \mathrm{mg} / \mathrm{L}$, respectively. Finally, Si concentrations had an increasing trend during the whole experiments from around 9 to $17 \mathrm{mg} / \mathrm{L}$ in column 1 . It is clear that $\mathrm{Si}$ concentrations are controlled by Si minerals solubility (e.g., neo-formed silicates).

In contrast, Fe concentrations in the non-amended scenario (column 4) went from an initial $3,500 \mathrm{mg} / \mathrm{L}$ to a final $107 \mathrm{mg} / \mathrm{L}$. Fe concentrations in the reactive tailings are controlled by a complex set of minerals including pyrite, chalcopyrite, HFO, Fe oxides, and jarosite (Doye et al., 2003). In fact, pyrite and jarosite were the main Fe minerals detected in the $\mathrm{XRD}$ analysis. The initial high concentrations of Fe might indicate high pyrite oxidation rates and high dissolution rates of Fe minerals. After that, it seemed that the rate of $\mathrm{Fe}$ precipitation was higher than the rate of oxidation and the coating of reactive grains, thus causing the concentration to drop.

Ca had similar concentrations in the amended and non-amended scenarios. Many reactive tailings can have a high content of $\mathrm{Ca}$ minerals and still generate acidic $\mathrm{pH}$. Calcite $\left(\mathrm{CaCO}_{3}\right)$ and gypsum $\left(\mathrm{CaSO}_{4} \mathrm{H}_{2} \mathrm{O}\right)$ were the $\mathrm{Ca}$ minerals detected in the $\mathrm{XRD}$ analysis.

$\mathrm{Mn}$ is a very common metal that can be found in acidic mine waters. At near neutral level of $\mathrm{pH}$, its removal is enhanced. However, in low $\mathrm{pH}$ conditions, formation of $\mathrm{HMO}$ is kinetically slow compared to HFO formation. For the non-amended scenario, Mn showed a decreasing trend from 25 to $0.3 \mathrm{mg} / \mathrm{L}$, implicating precipitation of secondary $\mathrm{Mn}$ minerals.

Al concentrations went from more than $1,500 \mathrm{mg} / \mathrm{L}$ to about $82 \mathrm{mg} / \mathrm{L}$. Al might be controlled by the dissolution of gibbsite (Cravotta III et al., 2015). A discontinuity of the Al curve is noticeable in the case of column 1 , meaning that Al was not always detected in 
the amended scenario. Low and stable $\mathrm{Na}$ (i.e. average of $0.5 \mathrm{mg} / \mathrm{L}$ ) and $\mathrm{K}$ (i.e. average of $1.2 \mathrm{mg} / \mathrm{L}$ ) concentrations in column 4 indicate low brine content in the reactive tailings.

Other potentially toxic metals, such a $\mathrm{Cu}, \mathrm{Co}, \mathrm{Zn}, \mathrm{Ni}$ and $\mathrm{Cr}$, had high concentrations in column 4. Since no minerals of these metals were detected in the XRD, they might be controlled by the dissolution / precipitation of secondary phases. Cu was within the range of $40-200 \mathrm{mg} / \mathrm{L}$. Co was below the detection limits in column 1, but in the case of column 4, it had a decreasing trend from 4 to $0.06 \mathrm{mg} / \mathrm{L}$. $\mathrm{Zn}, \mathrm{Ni}$ and $\mathrm{Cr}$ were within the ranges of $175-8 \mathrm{mg} / \mathrm{L}, 12-0.2 \mathrm{mg} / \mathrm{L}$ and $1.6-0.14 \mathrm{mg} / \mathrm{L}$, respectively.

In summary, the non-amended scenario (i.e., column 4) showed high concentrations of dissolved metals, while the amended scenario (i.e., column 1) showed high immobilization of dissolved metals. Table 3 shows the estimate removal efficiency, in percentage, for the most important metals based on their initial concentrations. This analysis, based on the initial concentrations for both the amended and non-amended scenarios, shows the significance of having the remediation treatment in a mine tailing. For example, the proposed remediation design ensures that approximately $99.93 \%$ of the high Fe loads are neutralized and are not dissolved in water. Other metals, such as Al and Co are also unlikely to dissolve and be transported in the leachate of the amended environment.

\subsubsection{Controls of $\mathrm{pH}$ on sulfate and dissolved metals/metalloids. Water quality analysis}

Based on the results presented in this study and those from previous studies (Nordstrom, 1982, Nordstrom et al., 1999 and PlumLee et al., 1999), it has been sufficiently demonstrated that low $\mathrm{pH}$ levels accelerate the release of heavy / toxic metals, which, in 
turn, can negatively affect the survival of aquatic life and have other harmful impacts on the environment.

For the purpose of interpreting the variations of the mine drainage water chemistry, a Ficklin diagram can be utilized (PlumLee et al., 1992 and PlumLee et al., 1999). The usual Ficklin diagram is a scattergram, in which the sum of the base metals $\mathrm{Zn}, \mathrm{Cu}, \mathrm{Pb}, \mathrm{Cd}, \mathrm{Co}$, $\mathrm{Ni}$ is plotted against the $\mathrm{pH}$. In addition, the Ficklin diagram can be adapted to create similar plots using parameters other than the above mentioned base metals.

Figure 7a shows a Ficklin diagram based on the results presented in the previous sections, including the amended (columns 1 and 2) and non-amended (column 4) scenarios. For the non-amended scenario, the diagram shows that the quality of the leachate is categorized near the threshold of the high acid-extreme metal and high acid-high metal groups. As shown in the results, the non-amended scenario had initial high metal concentrations followed by a decreasing trend in metal concentrations with a pH within the range 2 - 3 the entire time. Evidently, there was a dissolved metal reduction in column 4, but as the $\mathrm{pH}$ remained low, the metals concentrations were still high. For the amended scenario, the leachate quality is characterized by the near neutral-high metal and the near neutral-low metal groups. Similar to column 4, columns 1 and 2 also showed a decreasing trend in the metal concentrations, but obviously the initial concentrations in the amended scenarios were much lower. As the $\mathrm{pH}$ remained on the neutral level (i.e. 7 - 8) the entire time, the immobilization of dissolved metals was enhanced.

In addition, Figure $7 b$ shows adapted Ficklin diagrams for other important parameters like $\mathrm{Fe}, \mathrm{SO}_{4}, \mathrm{Al}$ and $\mathrm{Mn}$, for columns 1 and 4 . For column 1, where all the samples have a $\mathrm{pH}$ above 7 , the range of concentrations in sulfate and in other metals (i.e., $\mathrm{Fe}, \mathrm{Al}$, and $\mathrm{Mn}$ ) is 
relatively narrow, thus it is evident that it has an effective ARD neutralization process. On the other hand, in column 4 there is a wide range in sulfate and metal concentrations with a very narrow $\mathrm{pH}$ range, indicating the release of metals due to the high acidity.

For the implications of the outcome regarding water quality standards, U.S. Federal Regulations (EPA, 2002) provide general guidelines about effluent discharges related to coal mining. The only parameters that are regulated are $\mathrm{Fe}, \mathrm{Mn}, \mathrm{pH}$ and total suspended solids (TSS). The effluent in the amended scenario fully complies with these regulations, while for the case of the non-amended scenario, such standards are not met on both the instantaneous and average values as they are always higher than the maximum admissible. Moreover, the leachate in the amended scenarios complies, for many parameters (e.g., $\mathrm{Ba}, \mathrm{Cu}, \mathrm{Pb}, \mathrm{Ni}, \mathrm{Zn}$ ), even with the higher quality standards (EPA, 1994) such as those related to drinking water.

\subsection{PHREEQC Modeling}

Geochemical simulations were mainly focused in the amended scenario (i.e., column 1). However, some investigations for the non-amended scenario (i.e., column 4.) were also explored. Table 3 shows the initial aqueous solutions for the amended and non-amended scenarios, which are the main inputs to the model. In general, the model could fairly replicate most of the experimental results; however, several uncertainties related to the geochemical modeling remain. These uncertainties are related to the nonlinearity of the

system (Amos et al., 2004). Some of the main sources of error in the model could be the identification of the appropriate solid phases and the associated equilibrium constants for the precipitation reactions. 
Figure $8 \mathrm{a}$ shows the most important parameters (i.e. $\mathrm{pH}, \mathrm{SO}_{4}, \mathrm{Fe}, \mathrm{Ca}, \mathrm{Al}, \mathrm{Mn}$ ) modeled by PHREEQC against the respective measurements from the leachate of column1 (i.e., amended scenario). In terms of $\mathrm{pH}$ and sulfate, the results from the simulation (shown in red) are close to the experiments (shown in blue). The simulation curves for these parameters had a decreasing trend, most clearly visible in the case of sulfate. In the case of $\mathrm{pH}$, the model simulation began with a $\mathrm{pH}$ above 9 , and was not able to replicate the initial behavior of the system for the first 120 days, approximately. A slow saturation process within the column may explain the discrepancy between the model and experimental results during this time. As the amount of particles reacting slowly increases, it takes some time until the introduced alkalinity in the mixture reaches higher dissolution rates. This is why the $\mathrm{pH}$ from the leachate of column 1 is acidic at the beginning (see Figure 5a) but after a few days it reaches the neutral level. Another important conclusion is that the model was not very sensitive to the initial $\mathrm{pH}$ value given to the solution (Table 3). On the other hand, sulfate simulations showed a better adjustment to the experimental data during the entire time, indicating more sensitivity to the initial input sulfate concentration.

Dissolved metal concentrations were also modeled. Fe and $\mathrm{Ca}$ are typically the most important dissolved metals to be analyzed in ARD, since they are related to the pyrite oxidation and alkaline neutralization, respectively. Fe had an initial oscillatory behavior within the range of $2.5-3 \mathrm{mg} / \mathrm{L}$ and then experienced a small increase to $3-3.5 \mathrm{mg} / \mathrm{L}$. Although the Fe simulation curve also had an increasing trend after 200 days, it stayed around $0.5 \mathrm{mg} / \mathrm{L}$ lower than the experimental data. Al and $\mathrm{Mn}$ simulations were highly influenced by the initial input concentrations and their curves did not show major changes from the initial values. This might be due to various factors such as the magnitude of the 
concentrations (e.g., Al was below the detection limits in the majority of the samples) and the mineral solubility control (i.e., precipitation of $\mathrm{Al}$ and $\mathrm{Mn}$ minerals). In the specific case of $\mathrm{Mn}$, other factors such as bacterial activity might play an important role in its significant depletion. Microorganisms including heterotrophic bacteria Pseudomonas, Clostridium and Desulfovibrio can directly reduce Mn (Kuyukak, 2002). In other words, PHREEQC fails to replicate the initial behavior of metals such as $\mathrm{Mn}$, where additional factors such as bacterial activity may have some control on Mn mobility.

In addition, saturation indices (SI) were calculated to establish the probable mineral phases that might be controlling the aqueous composition of the leachates. Table 4 shows the SI calculations of the most important primary and secondary mineral phases in columns 1 and 4 . In general, the leachate in this amended scenario showed supersaturation with respect to HFO phases, which led to low metal concentrations, especially $\mathrm{Fe}$, because of the high sorption capacity of these phases that might also lead to the removal of $\mathrm{SO}_{4}$, for what the precipitation of jarosite could also contribute significantly (Jones et al., 2006). The geochemical model showed equilibrium with respect to gypsum, (e.g. $\mathrm{SO}_{4}$ usually decreases due to precipitation of gypsum) which was reasonable as there is an obvious acid neutralization process in this scenario; however, sulfate showed a conservative behavior within the range $1000-1500 \mathrm{mg} / \mathrm{L}$. Therefore sulfate concentrations were controlled by the dissolution of another sulfate mineral such as anhydrite. Despite an initial neutral $\mathrm{pH}$, the sulfate concentrations were relatively high (> $2000 \mathrm{mg} / \mathrm{L}$ ) which could be controlled by the dissolution of jarosite, which was undersaturated with respect to the solution composition.

Low Al concentrations in the amended scenario were controlled by the precipitation of gibbsite, k-mica and kaolinite. Mn concentrations were controlled by the precipitation of 
manganite and rhodrochrosite. Moreover, bacterial activity could also contribute to precipitation of $\mathrm{Mn}$ phases at a near neutral $\mathrm{pH}$.

Typically, the leachates from non-amended tailings are highly reactive, thus facilitating the dissolution of most of the primary minerals and the formation of the secondary phases. The leachate in this non-amended scenario showed undersaturation with respect to HFO phases, which led to higher metal concentrations, especially Fe. Moreover, decreasing sulfate concentrations were controlled by the precipitation of sulfate minerals such as gypsum, anhydrite and jarosite. In acid mine waters, Fe can reach saturation with respect to jarosite (Nordstrom, 1982). Unlike the amended scenario, in this case the Al concentrations were relatively high, similar to most reactive tailings. Al was controlled by the dissolution of several minerals such as gibbsite, k-mica, kaolinite, k-feldspar and chlorite. Al minerals like gibbsite are highly soluble with low pH (Nordstrom et al., 1999). Mn concentrations were controlled by the dissolution of manganite.

Finally, an extended 5-year simulation was performed for the amended scenario (see Figure $8 b)$. Although these results could not be taken as definitive, the fact that they were supported by a calibration process that replicated the initial 600 days of the system behavior made this exercise a valuable planning and decision making tool, especially in terms of the long-term effectiveness of the remediation approach described in this study. Obviously, these simulations are highly linked to the experimental data (e.g., calibration process). Upon retrieving more experimental data, another model validation should be performed.

The three most important $\mathrm{ARD}$ parameters (i.e., $\mathrm{pH}, \mathrm{SO}_{4}$ and $\mathrm{Fe}$ ) were analyzed in the long-term simulations. The $\mathrm{pH}$ showed an expected decreasing trend until it reached 
around 6.8 after 5 years of simulation. Sulfate data showed an initial decreasing trend, where simulations were adjusted to the experimental data, after that and until the end of the simulation time, it showed a more conservative behavior, only decreasing from approximately 1700 to $1500 \mathrm{mg} / \mathrm{L}$. According to the SI calculations for the amended scenario, the main sulfate mineral, gypsum, was at equilibrium $(\mathrm{SI} \sim 0)$ at all times. This might indicate that gypsum formation occurs quickly enough on pyrite grain surfaces that it remains close to saturation in the bulk phase (Dold, 2014 and Hammarstrom et al., 2003). Therefore, the factor controlling sulfate was the dissolution of secondary phases such as aragonite. This led to relatively low and conservative sulfate concentrations. Fe simulations showed an increasing trend, until it reached a concentration of $3.3 \mathrm{mg} / \mathrm{L}$ after 5 years. This low $\mathrm{Fe}$ concentration was controlled directly by the neutral $\mathrm{pH}$, which favored the precipitation of Fe phases.

\subsection{Implications for Long-Term performance of the remediation}

Field measurements, laboratory experiments and geochemical modeling have been analyzed jointly to determine the possible long-term behavior of the remediation proposed in this study. The determination of the necessary alkalinity supply is an important initial strategy for long-term ARD remediation (Huminicki et al., 2009). The static tests allowed to determine the minimum $\mathrm{AC} / \mathrm{CR}$ mixing ratio that provides the amount of alkalinity that, potentially, will make the system not ARD-generating. Furthermore, the performed kinetic tests and the field measurements validated the adoption of a $10 \% \mathrm{AC} / 90 \% \mathrm{CR}$ mixing ratio in terms of $\mathrm{pH}$, sulfate and metals/metalloids. At the end of the experiments, there was no indication of alkalinity exhaustion. 
It was observed that, for the amended scenario, the $\mathrm{pH}$ remained over 7 after 600 days. Moreover, there is a clear indication of metals/metalloids immobilization, as opposed to the non-amended scenario. However, even in the non-amended scenario, the concentrations of the majority of the metals (e.g. $\mathrm{Fe}, \mathrm{Mn}, \mathrm{Cr}, \mathrm{Cu}, \mathrm{Ni}, \mathrm{Zn}, \mathrm{Al}$ ) and sulfate showed a decreasing behavior, hence suggesting a decreasing alkalinity demand. Based on the results of the kinetic tests and field measurements retrieved over a period of 5 years, a geochemical simulation was performed (i.e. 600 days and 5 years) which indicated HFO formation in the amended scenario. This HFO formation can accelerate the consumption of sulfide minerals (Huminicki et al., 2009).

The longer the leachate remains on the alkaline side, the more enhanced the generation of iron precipitates that could produce the pyrite grain coating becomes. In addition, the pyrite grains and other sulfide minerals will dissolve in time (alkaline minerals will also dissolve), which means that, in the long term, once the majority of the AC is dissolved, the alkalinity demand in the mine tailing will be relatively small due to the combined processes of dissolution and coating of pyrite and other sulfide minerals. Furthermore, the precipitation of some minerals will make the amended layer less porous, thus increasing water retention and reducing oxygen diffusion. In summary, the combined processes have shown that the $\mathrm{pH}$ value can be kept around 7 for at least 600 days based on the column experiments (see Figure 5a) and for five years, based on the field measurements (see Figure 2) and numerical simulations (see Figure $8 b$ ). Such results strongly suggest that the utilization of $A C$ is beneficial for ARD long-term remediation.

\section{CONCLUSIONS}


This study investigated the potential use of $A C$ as a passive remediation material for waste coal mining that has the potential to generate ARD. Based on this study, AC is shown to be an effective remediation material. Results indicated that a $10 \% \mathrm{AC} / 90 \% \mathrm{CR}$ mixing ratio provides near-optimal remediation conditions. This mixing ratio is only considered as an upper remediation layer for the waste piles. Moreover, results suggested that this remediation approach has long-term stability (i.e., neutralization rate is equal to or higher than pyrite oxidation rate). Immobilization of contaminants, such as $\mathrm{Fe}, \mathrm{Mn}$ or $\mathrm{SO}_{4}$, and an increase in calcium carbonates implicated a strong pyrite ARD oxidation neutralization capability. Concentrations of other major contaminants, such as As and Al, were below the detection limits in the amended scenario.

Field measurements have also proved that the use of $A C$ is beneficial to remediate the acid drainage in the coal waste. During the period of time in which these measurements were made, $\mathrm{pH}$ showed an increase in the amended plots; at the same time, sulfate and dissolved metals showed a decreasing behavior in these plots. However, there are some improvements that could be made to this field remediation approach in order to increase its effectiveness. These included soil compaction in the amended layer and the utilization of ground particles of $A C$ to increase the surface area of the neutralizer and decrease the porosity of the medium. Long term and continuous data would also be crucial for this characterization.

Future work should consider extending the experimentation time and settings, focusing on the following particular issues:

- The estimation of the optimal amended depth. 
- The assessment of the impact of vegetation in the amended and non-amended layer.

- The influence of the remediation in the interphase zone (amended / non-amended layer).

- The potential use of another remediation approach that can be combined with the one presented in this study.

- The simulation of the ARD remediation processes under a more physically-based modeling framework.

\section{ACKNOWLEDGEMENTS}

This work was supported in part by the U.S. National Science Foundation under CBET1236403 to the University of Pittsburgh. We gratefully acknowledge the help and field data provided by Judodine Nichols, Jaw K. Fu, and Peter Koranchie-Boah from the Aloca Technical Center. Co-author, Xu Liang, also acknowledges the support from the William Kepler Whiteford Professorship from the University of Pittsburgh.

\section{REFERENCES}

Amos, R. T., Mayer, K. U., Blowes, D. W., \& Ptacek, C. J. (2004). Reactive transport modeling of column experiments for the remediation of acid mine drainage. Environmental Science and Technology, 38(11), 3131-3138. doi:10.1021/es0349608

Appelo, C. A. J., Verweij, E., \& Schäfer, H. (1998). A hydrogeochemical transport model for an oxidation experiment with pyrite/calcite/exchangers/organic matter containing sand. Applied Geochemistry, 13(2), 257-268. doi:10.1016/S0883-2927(97)00070-X

Banks, D. (2006). Assessment of the impact of the mine flooding process on groundwater quality; chemical and mineralogical analysis of rock samples recovered from Janina Mine. In Hydrogeological Modelling of Water Evolution, Final report of WaterNorm Project, European Union Grant No. MTKD-CT-2004-003163, 55Pp. 
Brady, K.B.C., and Cravotta, C.A., III, 1992, Acid-base accounting - an improved method of interpreting overburden chemistry to predict quality of coal mine drainage, in Proceedings of the 13th Annual Meeting, West Virginia Surface Mine Drainage Task Force, WVU: Morgantown, West Virginia.

Britton, H.T.S., 1955. Hydrogen lons, fourth ed. Chapman and Hall, London.

Chandra, A. P., \& Gerson, A. R. (2010). The mechanisms of pyrite oxidation and leaching: A fundamental perspective. Surface Science Reports, 65(9), 293-315. doi:10.1016/j.surfrep.2010.08.003

Chaplin, J. J., Cravotta III, C. A., Weitzel, J. B., Klemow, K. M., (2007). Effects of Historical Coal Mining and Drainage from Abandoned Mines on Streamflow and Water Quality in Newport and Nanticoke Creeks, Luzerne County, Pennsylvania, 1999-2000. U. S. Geological Survey, Scientific Investigations Report 2007-5061.

Cravotta III, C. A. (2008). Dissolved metals and associated constituents in abandoned coal-mine discharges, Pennsylvania, USA. Part 1: Constituent quantities and correlations, Applied Geochemistry, 23(2), 166-202, doi:10.1016/j.apgeochem.2007.10.011.

Cravotta III, C.A., Brady, K.B.C. (2015). Priority pollutants and associated constituents in untreated and treated discharges from coal mining or processing facilities in Pennsylvania, USA. Applied Geochemistry,62,108-130, ISSN 0883-2927, http://dx.doi.org/10.1016/j.apgeochem.2015.03.001.

Dold, B. (2014). Evolution of Acid Mine Drainage Formation in Sulphidic Mine Tailings. Minerals, 4, 621-641; doi:10.3390/min4030621

Doye, I., \& Duchesne, J. (2003). Neutralisation of acid mine drainage with alkaline industrial residues: Laboratory investigation using batch-leaching tests. Applied Geochemistry, 18(8), 1197-1213. doi:10.1016/S0883-2927(02)00246-9

Evangelou, V. P. (1995). Pyrite oxidation and its control: Solution chemistry, surface chemistry, acid mine drainage (AMD), molecular oxidation mechanisms, microbial role, kinetics, control, ameliorates and limitations, microencapsulation. Boca Raton, FL: CRC Press.

Garrels, R.M., Thompson, M.E. (1960). Oxidation of pyrite by iron sulfate solutions. American Journal of Science, 258-A, pp. 57-67

Hammarstrom, J. M., Sibrell, P. L., Belkin, H. E. (2003). Characterization of limestone reacted with acid-mine drainage in a pulsed limestone bed treatment system at the 
Friendship Hill National Historical Site, Pennsylvania, USA. Applied Geochemistry, 18 (11), 1705-1721, ISSN 0883-2927, dx.doi.org/10.1016/S0883-2927(03)00105-7.

Hammarstrom, J. M., Seal, R. R., Meier, A. L., \& Kornfeld, J. M. (2005). Secondary sulfate minerals associated with acid drainage in the eastern US: Recycling of metals and acidity in surficial environments. Chemical Geology, 215(1), 407-431. doi:10.1016/j.chemgeo.2004.06.053

Heikkinen, P. M., Räisänen, M. L., \& Johnson, R. H. (2009). Geochemical characterisation of seepage and drainage water quality from two sulphide mine tailings impoundments: Acid mine drainage versus neutral mine drainage. Mine Water and the Environment, 28(1), 30-49. doi:10.1007/s10230-008-0056-2

Hengen, T. J., Squillace, M. K., O'Sullivan, A. D., \& Stone, J. J. (2014). Life cycle assessment analysis of active and passive acid mine drainage treatment technologies. Resources, Conservation \& Recycling, 86, 160.

Herlihy AT, Kaufmann PR, Mitch ME, Brown DD (1990) Regional estimates of acid mine drainage impact on streams in the mid-Atlantic and southeastern United States. Water Air Soil Pollut 50:91-107

Huminicki, D. M. C., \& Rimstidt, J. D. (2009). Iron oxyhydroxide coating of pyrite for acid mine drainage control. Applied Geochemistry, 24(9), 1626-1634. doi:10.1016/j.apgeochem.2009.04.032

Johnson, D. B., \& Hallberg, K. B. (2005). Acid mine drainage remediation options: A review. Science of the Total Environment, 338(1), 3-14. doi:10.1016/j.scitotenv.2004.09.002

Jones, Elizabeth, J. P., Nadeau, T., Voytek, M. A., \& Landa, E. R. (2006). Role of microbial iron reduction in the dissolution of iron hydroxysulfate minerals. Journal of Geophysical Research - Biogeosciences, 111(G1), G01012. doi:10.1029/2005JG000089

Kuyukak, N., (2002). Role of Microorganisms in Mining: Generation of Acid Rock Drainage and its Mitigation and Treatment. The European Journal of Mineral Processing and Environmental Protection Vol.2, No.3, 1303-0868, 2002, pp. 179-196

Motalebi Damuchali, A., Asadollahfardi, G., \& Khodadadi, A. (2012). Effective parameter predictions in metals transport from the Zanjan zinc mine tailings using PHREEQC. Mine Water and the Environment, 31(4), 339-343. doi:10.1007/s10230-012-0201-9 
Nordstrom, D. K. (1982) Aqueous pyrite oxidation and the consequent formation of secondary iron minerals, InKittrick, J. A., Fanning, D. S., and Hossner, L. R., eds., Acid Sulfate Weathering, Soil Sci. Soc. Am. Publ., 37- 56.

Nordstrom, D.K. and Alpers, C.N. (1999), Geochemistry of acid mine waters. In Reviews in Economic Geology, vol. 6A, The Environmental Geochemistry of Mineral Deposits. Part A. Processes, Methods and Health Issues, G.S.PlumLee and M.J. Logsdon, eds., Soc. Econ. Geol., Littleton, CO. 133-160.

Parkhurst, D. L., Appelo, C. A. J., \& Geological Survey (U.S.). (1999). User's guide to PHREEQC (version 2): A computer program for speciation, batch-reaction, onedimensional transport, and inverse geochemical calculations. Denver, Colo: U.S. Geological Survey.

Parkhurst, D. L., Appelo, C. A. J., \& Geological Survey (U.S.). (2013). Description of input and examples for PHREEQC version 3--a computer program for speciation, batchreaction, one-dimensional transport, and inverse geochemical calculations. Reston, Virginia: U.S. Department of the Interior, U.S. Geological Survey.

Pérez-López, R., Quispe, D., Castillo, J., \& Nieto, M. (2011). Acid neutralization by dissolution of alkaline paper mill wastes and implications for treatment of sulfidemine drainage. American Mineralogist, 96(5), 781-791. doi:10.2138/am.2011.3685

PlumLee, G.S., Smith, K.S., Ficklin, W.H., and Briggs, P.H., 1992, Geological and geochemical controls on the composition of mine drainages and natural drainages in mineralized areas: Proceedings, 7th Internatl.Water-Rock Interaction Conference, Park City, Utah, July 1992, pp. 419-422.

PlumLee GS, Smith KS, Montour MR, Ficklin WH, Mosier EL (1999) Geologic controls on the composition of natural waters and mine waters draining diverse mineral-deposit types. In: Filipek LH, PlumLee GS (eds) The environmental geochemistry of mineral deposits, Part B: case studies and research topics, Rev Econ Geol 6B:373-432

Price, W.A., Errington, J., and Koyanagi, V, 1997, Guidelines for the prediction of acid rock drainage and metal leaching for mines in British Columbia: part I. General procedures and information requirements: MEND, Natural Resources Canada, Ottawa, Proceedings of the 4th International Conference on Acid Rock Drainage 1, p. 1-14.

Runkel, R. L., Kimball, B. A., Walton-Day, K., Verplanck, P. L., \& Broshears, R. E. (2012). Evaluating remedial alternatives for an acid mine drainage stream: $A$ model post audit. Environmental Science and Technology, 46(1), 340-347. doi:10.1021/es2038504 
U.S. Environmental Protection Agency - EPA (1994). Summary of EPA finalized National primary drinking water regulations: U.S. Environmental Protection Agency Region VIII, $7 p$

U.S. Environmental Protection Agency - EPA (2002). Coal Mining Point Source Category: Effluent Limitations Guidelines and New Source Performance Standards. 40 CFR Part 434.

Sahoo, P. K., Tripathy, S., Panigrahi, M. K., \& Equeenuddin, S. M. (2013). Inhibition of acid mine drainage from a pyrite-rich mining waste using industrial by-products: Role of neo-formed phases. Water, Air, \& Soil Pollution, 224(11), 1-11. doi:10.1007/s11270013-1757-0

Sams, J. I., Beer, K. M., (2000). Effects of coal-mine drainage on stream water quality in the Allegheny and Monongahela River basins: sulfate transport and trends, U.S. Geological Survey, Water-Resources Investigations Report 99-4208.

Singer, P.C., Stumm, W. (1970). Acidic mine drainage: The rate-determining step. Science, 167 , pp. 1121-1123

Sobek, A.A., Schuller, W.A., Freeman, J.R., Smith, R.M., 1978. Field and Laboratory Methods Applicable to Overburden and Mine Soils. EPA. 600/2-78-054.

Sracek, O., Gzyl, G., Frolik, A., Kubica, J., Bzowski, Z., Gwodziewicz, M., \& Kura, K. (2010). Evaluation of the impacts of mine drainage from a coal waste pile on the surrounding environment at smolnica, southern poland. Environmental Monitoring and Assessment, 165(1-4), 233-254. doi:10.1007/s10661-009-0941-6

Sun, J., Tang, C., Wu, P., Strosnider, W. H. J., \& Han, Z. (2013). Hydrogeochemical characteristics of streams with and without acid mine drainage impacts: A paired catchment study in karst geology, SW china. Journal of Hydrology, 504, 115-124. doi:10.1016/j.jhydrol.2013.09.029

Webster, J. G., Swedlund, P. J., \& Webster, K. S. (1998). Trace metal adsorption onto an acid mine drainage iron(III) oxy hydroxy sulfate. Environmental Science and Technology, 32(10), 1361-1368. doi:10.1021/es9704390

Williams, D. R., Clark, M. E., Brown, J. B., (1990). Stream Water Quality in Coal Mined Areas of the Lower Cheat River Basin, West Virginia and Pennsylvania, During Low-Flow Conditions. U. S. Geological Survey, Water-Resources Investigations Report 98-4258

Williamson, M.A., Rimstidt, J.D. (1994). The kinetics and electrochemical rate-determining step of aqueous pyrite oxidation. Geochim. Cosmochim. Acta, 58. p. 5443-5454. 
Williamson, M.A., Kirby, C.S., Rimstidt, J.D. (2006). Iron dynamics in acid mine drainage. In: Barnhisel, R.I. (Ed.), 7th Internat. Conf. Acid Rock Drainage. American Society of Mining and Reclamation, Lexington, KY 40502, St. Louis MO, pp. 2411-2423.

Yee, N., Shaw, S., Benning, L.G., Hien Nguyen, T. (2006). The rate of ferrihydrite transition to goethite via the $\mathrm{Fe}(\mathrm{II})$ pathway. Am. Mineral. 91, 92-96.

Younger, P.L., Banwart, S.A., Hedin, R.S. (2002). Mine water: hydrology, pollution, remediation. Springer Publishing, New York, NY 
Table 1. Solid compositions of Coal Refuse (CR) and Alkaline Clay (AC) (Source: ALCOA)

\begin{tabular}{|c|c|}
\hline Coal Refuse Composition & Percentage $(\%)$ \\
\hline Quartz: $\mathrm{SiO}_{2}$ & 55.6 \\
\hline K-mica: $\mathrm{KAl}_{2}\left(\mathrm{AlSi}_{3} \mathrm{O}_{10}(\mathrm{OH})_{2}\right)$ & 24.0 \\
\hline Jarosite-K: $\mathrm{KFe}_{3}(\mathrm{OH})_{6}\left(\mathrm{SO}_{4}\right)_{2}$ & 9.9 \\
\hline Kaolinite: $\mathrm{Al}_{2} \mathrm{O}_{3} 2 \mathrm{SiO}_{2} 2 \mathrm{H}_{2} \mathrm{O}$ & 8.3 \\
\hline Calcite: $\mathrm{CaCO}_{3}$ & 1.0 \\
\hline Gypsum: $\mathrm{CaSO}_{4} \cdot 2 \mathrm{H}_{2} \mathrm{O}$ & 0.9 \\
\hline Pyrite: $\mathrm{FeS}_{2}$ & 0.3 \\
\hline Alkline Clay Composition & Percentage $(\%)$ \\
\hline Dicalcium silicate: $2 \mathrm{CaO}(\mathrm{SiO})_{2}$ & 57 \\
\hline Sodalite: $\mathrm{Na}_{8}\left(\mathrm{Al}_{6} \mathrm{Si}_{6} \mathrm{O}_{24}\right) \mathrm{Cl}_{2}$ & 12 \\
\hline Gehlenite: $\mathrm{Ca}_{2} \mathrm{Al}\left(\mathrm{AlSiO}_{7}\right)$ & 10 \\
\hline Hematite: $\mathrm{Fe}_{2} \mathrm{O}_{3}$ & 8 \\
\hline Calcium aluminum sulfate: $\mathrm{Ca}_{6} \mathrm{Al}_{2}\left(\mathrm{SO}_{4}\right)_{3}(\mathrm{OH})_{12} \cdot 26 \mathrm{H}_{2} \mathrm{O}$ & 2 \\
\hline Calcium titanium oxide: $\mathrm{CaTiO}_{3}$ & 2 \\
\hline Quartz: $\mathrm{SiO}_{2}$ & 3 \\
\hline Titanium dioxide: $\mathrm{TiO}_{2}$ & 2 \\
\hline Calcium carbonate: $\mathrm{CaCO}_{3}$ & 3 \\
\hline Gibbsite: $\mathrm{Al}(\mathrm{OH})_{3}$ & 1 \\
\hline
\end{tabular}


Table 2. Metal removal efficiency

\begin{tabular}{cccc}
\hline Description & $\begin{array}{c}\text { Initial } \\
\text { Concentration } \\
\text { Column } 4 \\
(\mathrm{mg} / \mathrm{l})\end{array}$ & $\begin{array}{c}\text { Initial } \\
\text { Concentration } \\
\text { Column } 1 \\
(\mathrm{mg} / \mathrm{l})\end{array}$ & $\begin{array}{c}\text { Removal } \\
(\%)\end{array}$ \\
\hline $\mathrm{Fe}$ & 3496 & 2.33 & 99.93 \\
$\mathrm{Mn}$ & 24.9 & 0.90 & 96.39 \\
$\mathrm{Cu}$ & 160 & 0.04 & 99.98 \\
$\mathrm{Cr}$ & 1.6 & 0.003 & 99.84 \\
$\mathrm{Zn}$ & 106.5 & 0.50 & 99.53 \\
$\mathrm{Ni}$ & 11.7 & 0.07 & 99.40 \\
$\mathrm{Al}$ & 1518 & 0.01 & 100.00 \\
$\mathrm{Co}$ & 4.2 & 0.00 & 100.00
\end{tabular}


Table 3. PHREEQC initial solutions (amended and non-amended scenarios)

\begin{tabular}{|c|c|c|}
\hline & $\begin{array}{l}\text { Amended } \\
\text { Scenario }\end{array}$ & $\begin{array}{c}\text { Non-amended } \\
\text { Scenario } \\
\end{array}$ \\
\hline Description & $\begin{array}{l}\text { Concentration } \\
(\mathrm{mg} / \mathrm{l})\end{array}$ & $\begin{array}{c}\text { Concentration } \\
(\mathrm{mg} / \mathrm{l})\end{array}$ \\
\hline $\mathrm{Al}$ & 0.05 & 200 \\
\hline $\mathrm{Ba}$ & 0.01 & 0.01 \\
\hline $\mathrm{Ca}$ & 500 & 550 \\
\hline $\mathrm{Cu}$ & 0.04 & 100 \\
\hline $\mathrm{Fe}$ & 2.50 & 200 \\
\hline K & 4.00 & 0.50 \\
\hline $\mathrm{Mg}$ & 100 & 150 \\
\hline $\mathrm{Mn}$ & 0.20 & 5.00 \\
\hline $\mathrm{Na}$ & 120 & 0.40 \\
\hline $\mathrm{SO}_{4}$ & 1800 & 8000 \\
\hline $\mathrm{Si}$ & 9.00 & 40 \\
\hline $\mathrm{Zn}$ & 0.80 & 100 \\
\hline $\mathrm{pH}$ & 7.00 & 2.50 \\
\hline
\end{tabular}


Table 4. PHREEQC Saturation Indices (amended and non-amended scenarios)

Amended Scenario

\begin{tabular}{|c|c|c|c|}
\hline Description & Chemical Formula & Initial SI & Final SI \\
\hline Anhydrite & $\mathrm{CaSO}_{4}$ & -0.36 & -0.36 \\
\hline Aragonite & $\mathrm{CaCO}_{3}$ & 1.85 & 1.85 \\
\hline Dolomite & $\mathrm{CaMg}\left(\mathrm{CO}_{3}\right)_{2}$ & 3.52 & 3.11 \\
\hline Iron(III) oxide-hydroxide & $\mathrm{Fe}(\mathrm{OH})_{3}$ & 2.79 & 2.79 \\
\hline Gibbsite & $\mathrm{Al}(\mathrm{OH})_{3}$ & -0.92 & 1.66 \\
\hline Gypsum & $\mathrm{CaSO}_{4} \cdot 2 \mathrm{H}_{2} \mathrm{O}$ & 0.00 & 0.00 \\
\hline Jarosite-K & $\mathrm{KFe}_{3}\left(\mathrm{SO}_{4}\right)_{2}(\mathrm{OH})_{6}$ & -6.28 & 0.76 \\
\hline K-mica & $\mathrm{KAl}_{3} \mathrm{Si}_{3} \mathrm{O}_{10}(\mathrm{OH})_{2}$ & 2.28 & 8.41 \\
\hline Kaolinite & $\mathrm{Al}_{2} \mathrm{Si}_{2} \mathrm{O}_{5}(\mathrm{OH})_{4}$ & -1.25 & 4.59 \\
\hline Manganite & $\mathrm{MnO}(\mathrm{OH})$ & 9.03 & 3.79 \\
\hline Quartz & $\mathrm{SiO}_{2}$ & -0.11 & 0.24 \\
\hline Rhodochrosite & $\mathrm{MnCO}_{3}$ & 0.60 & 0.19 \\
\hline \multicolumn{4}{|c|}{ Non-amended Scenario } \\
\hline Description & Chemical Formula & Initial SI & Final SI \\
\hline Anhydrite & $\mathrm{CaSO}_{4}$ & 0.13 & 0.13 \\
\hline Iron(III) oxide-hydroxide & $\mathrm{Fe}(\mathrm{OH})_{3}$ & -1.83 & -1.90 \\
\hline Gibbsite & $\mathrm{Al}(\mathrm{OH})_{3}$ & -4.25 & -4.43 \\
\hline Gypsum & $\mathrm{CaSO}_{4} \cdot 2 \mathrm{H}_{2} \mathrm{O}$ & 0.43 & 0.43 \\
\hline Jarosite-K & $\mathrm{KFe}_{3}\left(\mathrm{SO}_{4}\right)_{2}(\mathrm{OH})_{6}$ & 1.71 & 1.68 \\
\hline K-mica & $\mathrm{KAl}_{3} \mathrm{Si}_{3} \mathrm{O}_{10}(\mathrm{OH})_{2}$ & -12.98 & -13.59 \\
\hline Kaolinite & $\mathrm{Al}_{2} \mathrm{Si}_{2} \mathrm{O}_{5}(\mathrm{OH})_{4}$ & -6.02 & -6.39 \\
\hline Manganite & $\mathrm{MnO}(\mathrm{OH})$ & -4.10 & -4.22 \\
\hline Quartz & $\mathrm{SiO}_{2}$ & 0.82 & 0.82 \\
\hline Geothite & $\mathrm{FeO}(\mathrm{OH})$ & 4.06 & 3.99 \\
\hline K-feldspar & $\mathrm{KAlSi}_{3} \mathrm{O}_{8}$ & -10.09 & -10.34 \\
\hline Chlorite & $\mathrm{Mg}_{5} \mathrm{Al}_{2} \mathrm{Si}_{3} \mathrm{O}_{10}(\mathrm{OH})_{8}$ & -58.42 & -59.40 \\
\hline
\end{tabular}


a)

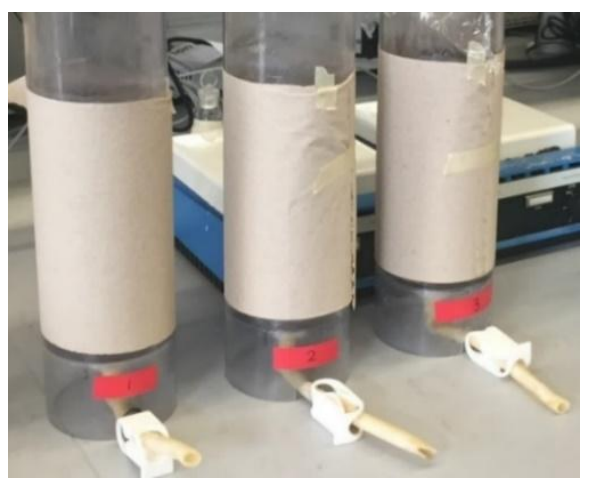

b)

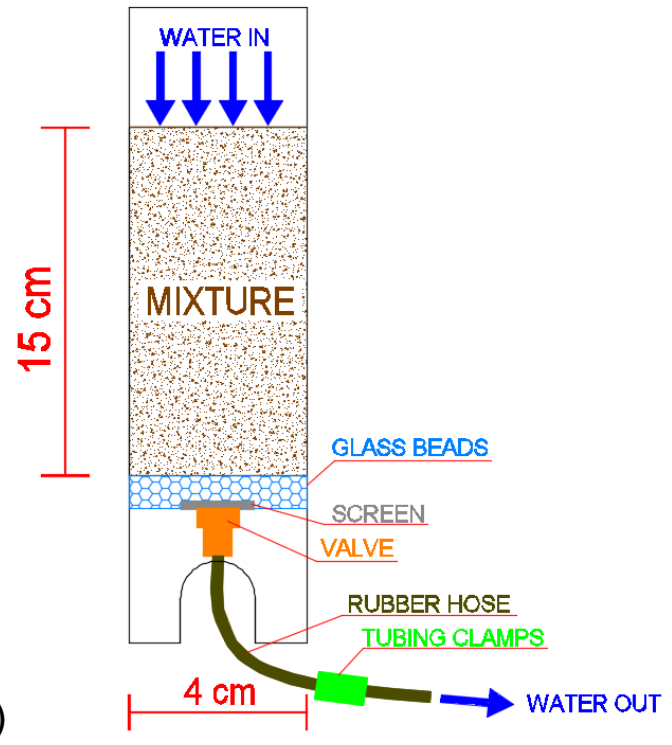

Figure 1. Column Experiments: a) Image of the columns, showing the covered sides b) Schematic design of the columns 

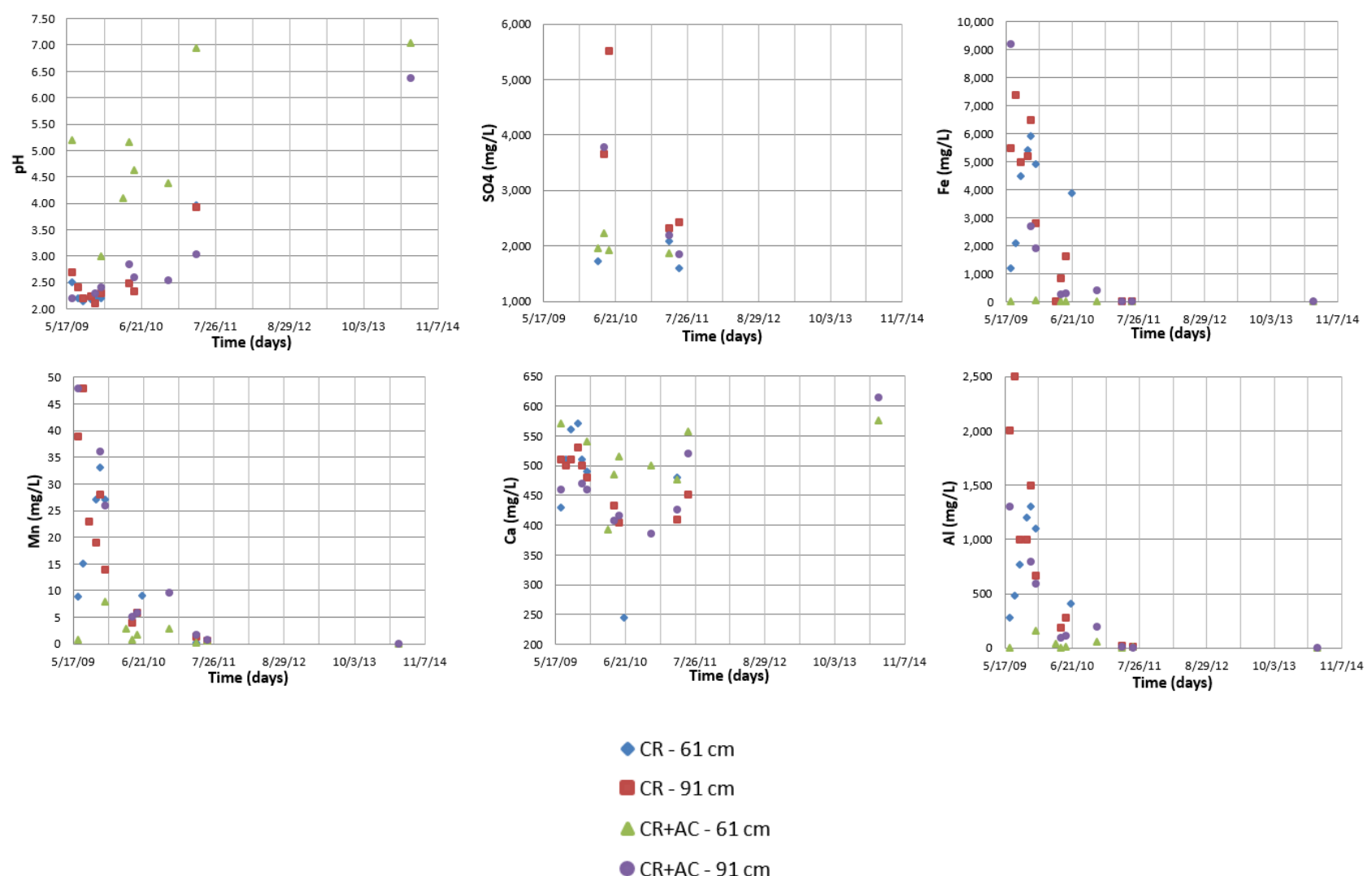

Figure 2. Field Measurements for plots $1(100 \% \mathrm{CR})$ and $2(90 \% \mathrm{CR}+10 \% \mathrm{AC})$. Plot 1 was replaced by the materials of plot 2 in spring of 2011 . 
a)
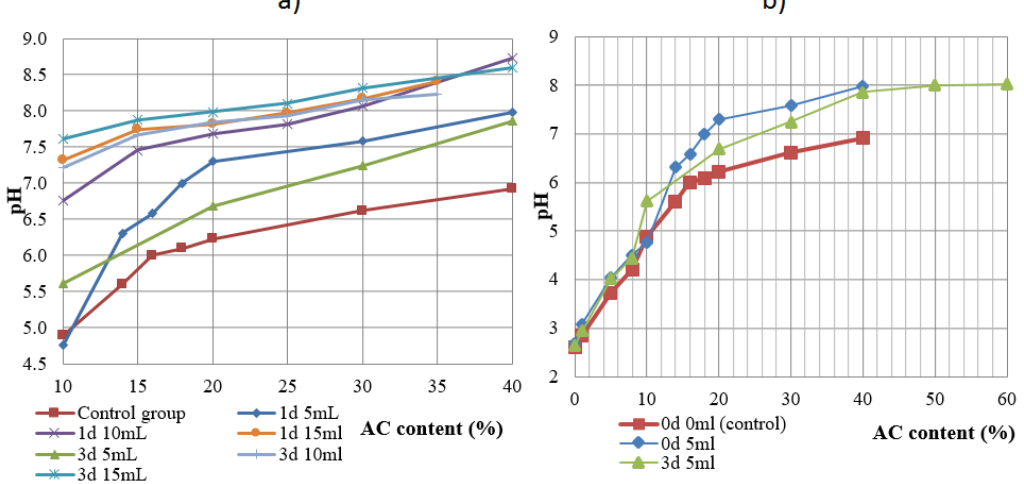

c)

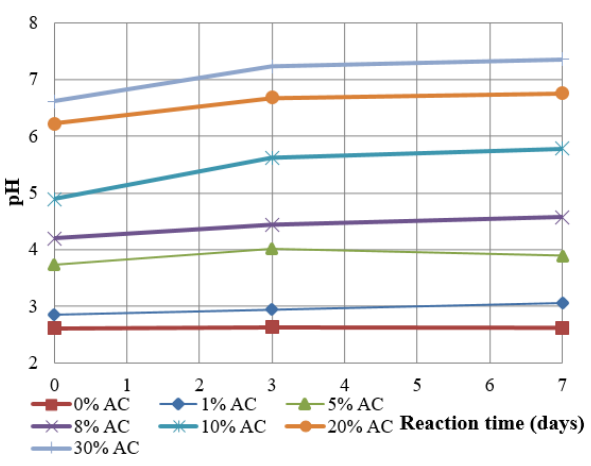

Figure 3. Results of batch experiments: a) pH versus percentage of $A C$ with different reaction days and water addition amounts. b) $\mathrm{pH}$ versus percentage of $A C$ with $5 \mathrm{ml}$ water addition for 0 and 3 reaction days. $\mathrm{c}$ ) $\mathrm{pH}$ versus reaction time with different percentage of $\mathrm{AC}$. In a) and b), the control group corresponds to 0 day reaction time and no water addition. 
a)

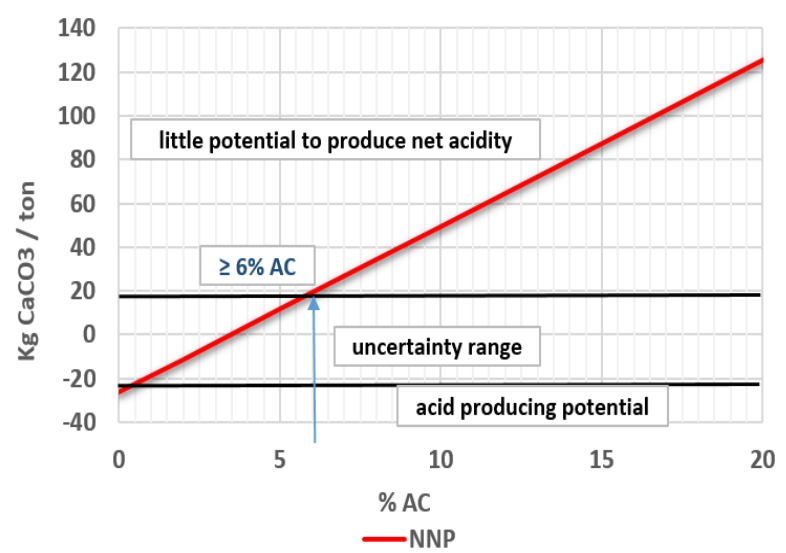

b)

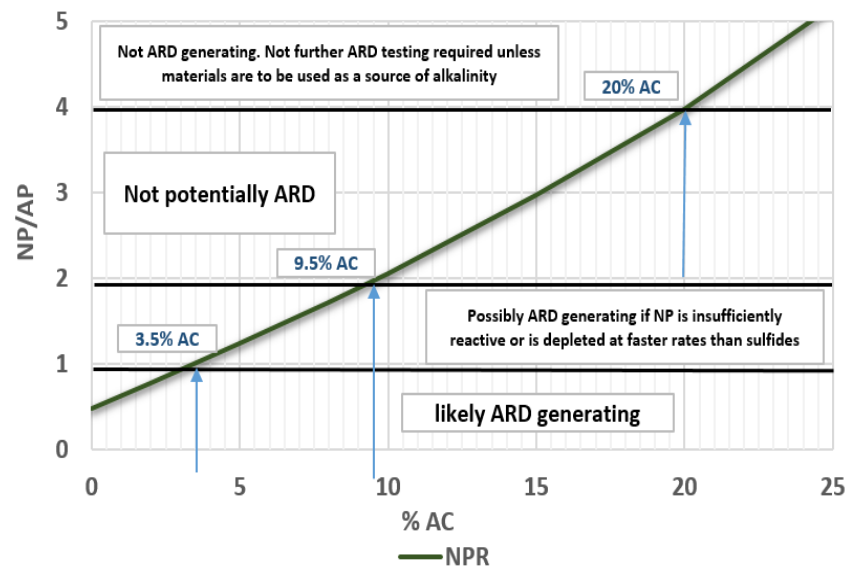

Figure 4. Acid Base Accounting Test Results Interpretation, based on the sample's \%AC.

a) Net Neutralization Potential (NNP) criteria. b) Neutralization Potential Ratio (NPR) criteria. $\mathrm{NP}=$ neutralization potential, $\mathrm{AP}=$ acid production potential, $\mathrm{NNP}=$ net neutralization potential, NPR=neutralization potential ratio. 
a)

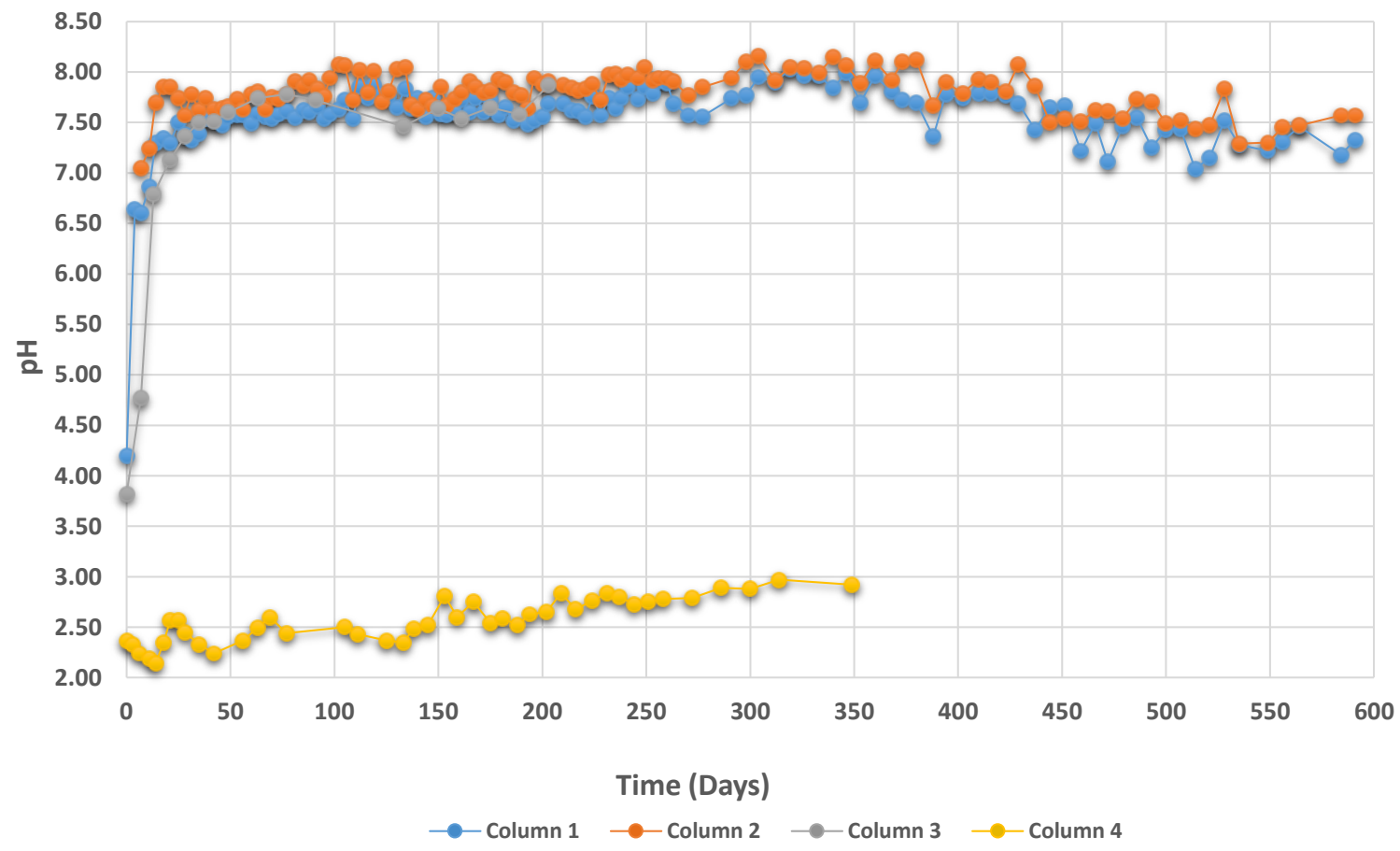

b)

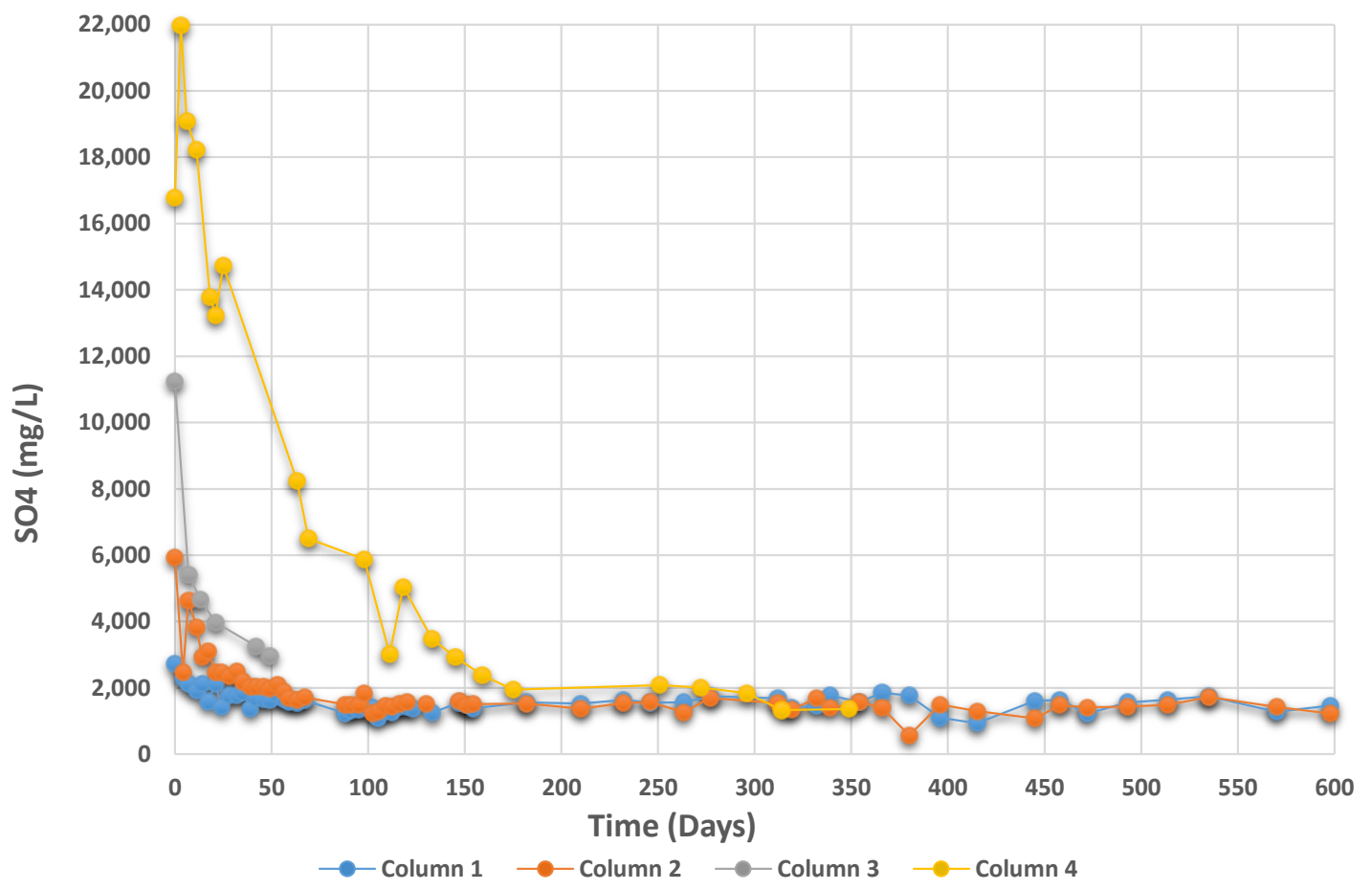

Figure 5. a) $\mathrm{pH}$ and b) sulfate results from the column leaching experiments. Column 1: 10\%AC+90\%CR. Column 2: 10\%AC+90\%CR (ground particles). Column 3: $10 \% A C+90 \%$ CR (less amount of water added). Column 4: $100 \% \mathrm{CR}$ 

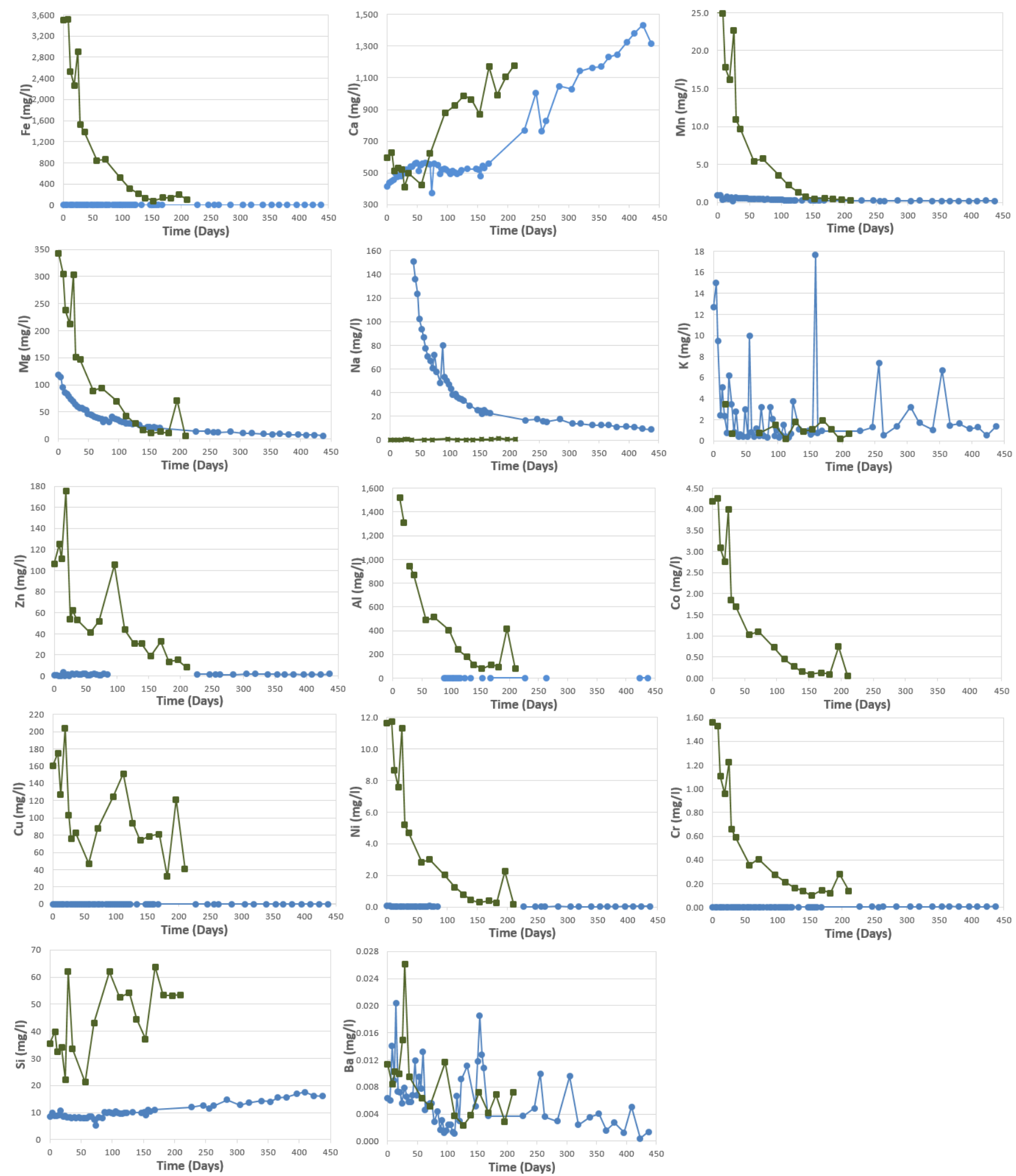

- Column $1 \rightarrow$ Column 4

Figure 6. ICP-MS results for the column experiments (Columns 1 and 4) 
a)

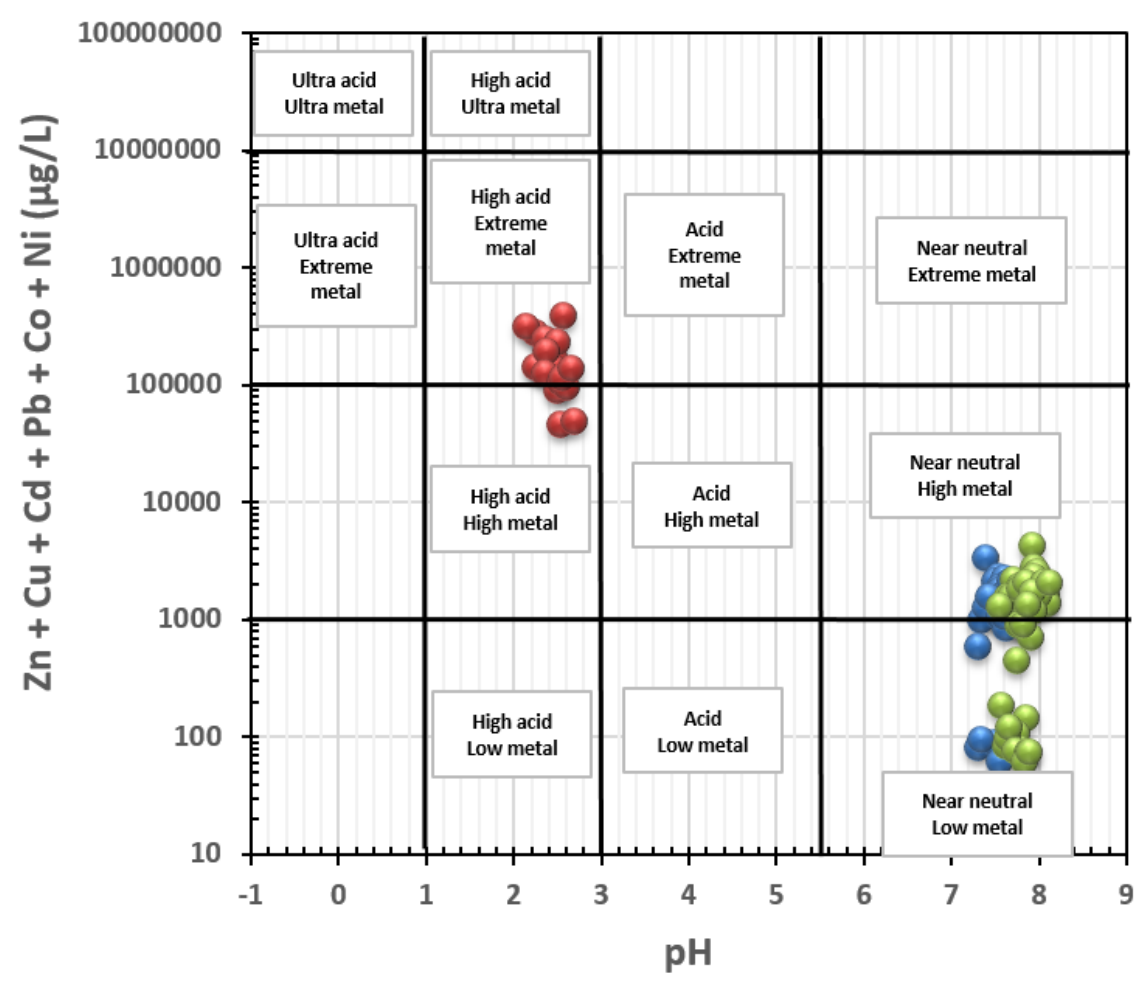

\section{Column 1 Column 2 Column 4}

b)
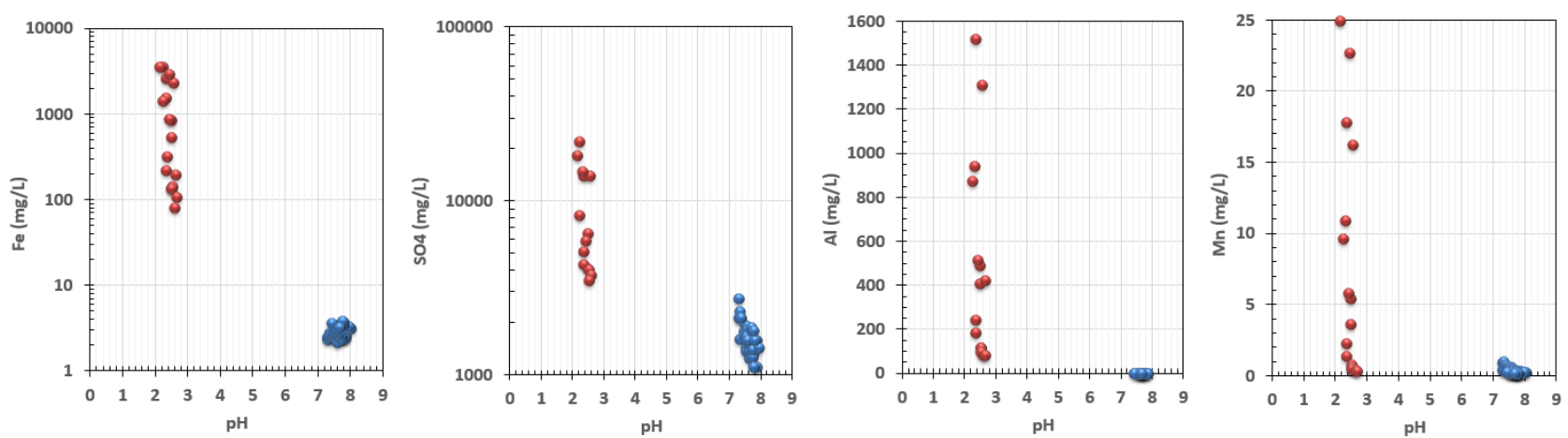

\section{Column 1 Column 4}

Figure 7. Ficklin diagrams for the column leaching experiments (Columns 1, 2 and 4) 
a)
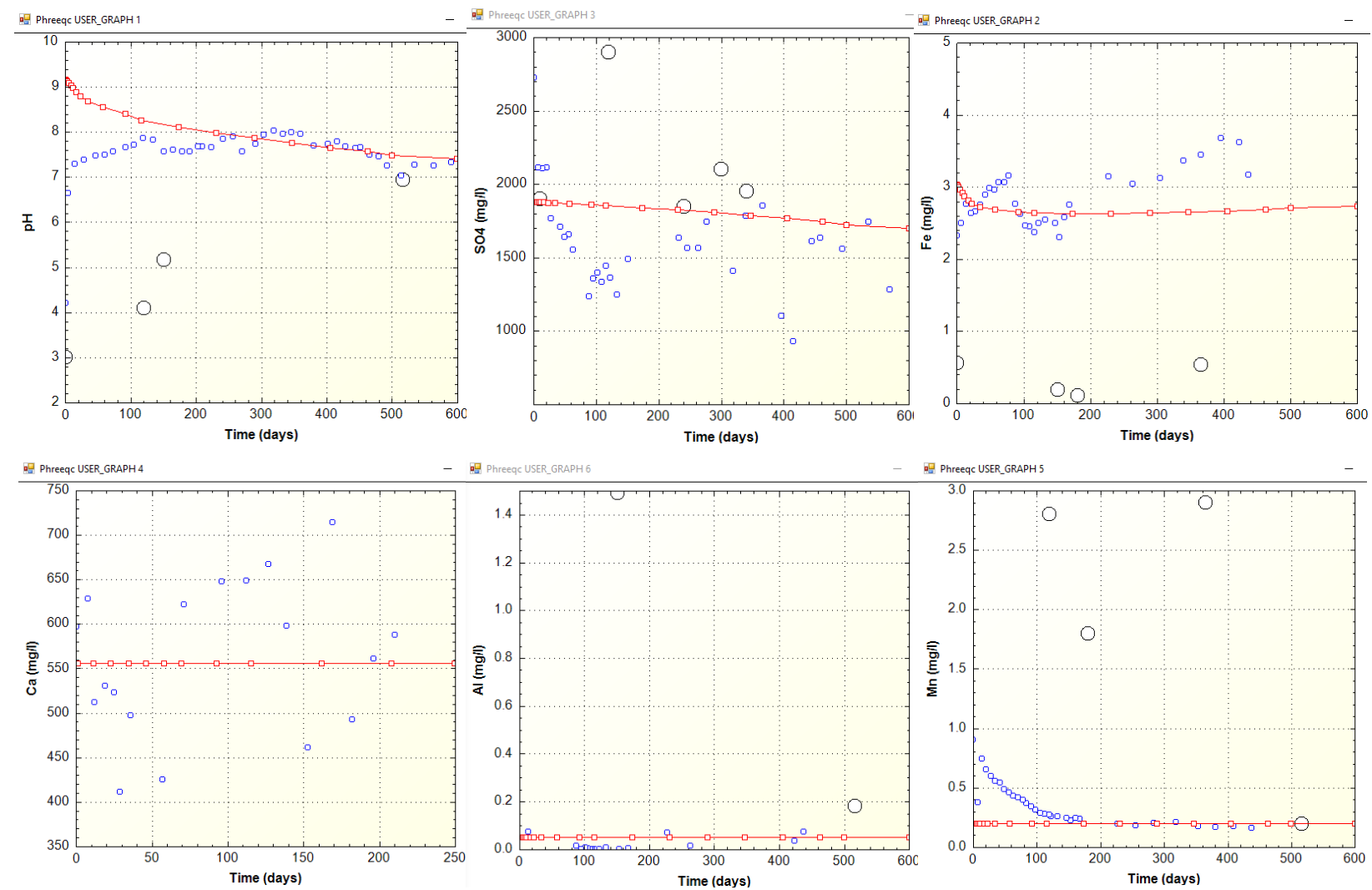

b)
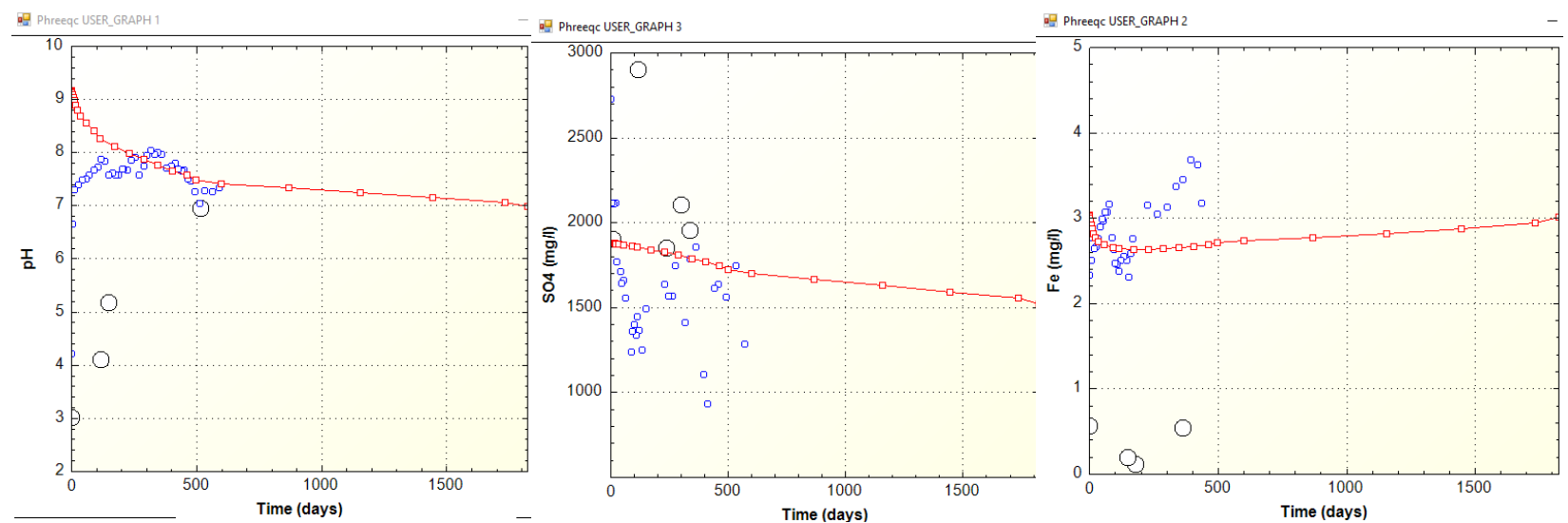

Figure 8. a) PHREEQC modeling results for the amended scenario (read circle line). The blue circles represent the experimental measurements (column 1). The large black circles represent the field measurements at $61 \mathrm{~cm}$ depth (plot 2). b) PHREEQC 5-year simulation for the amended scenario (column 1) 


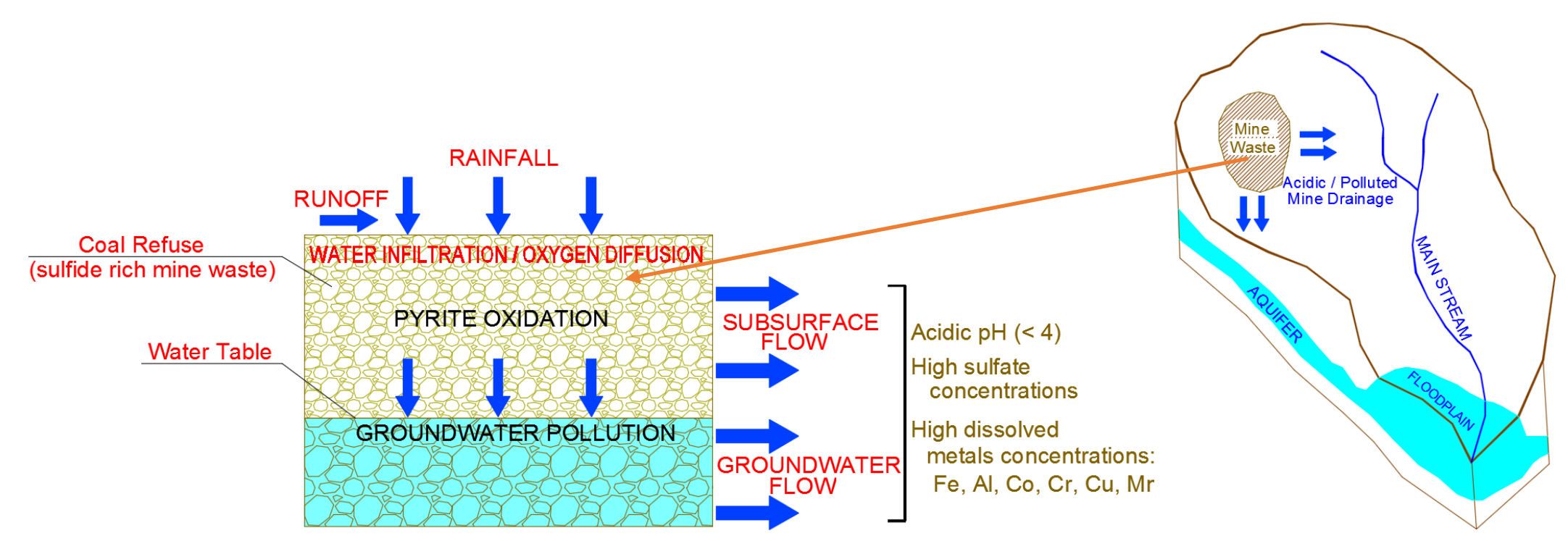

ACID ROCK DRAINAGE REMEDIATION

Coal Refuse (CR)

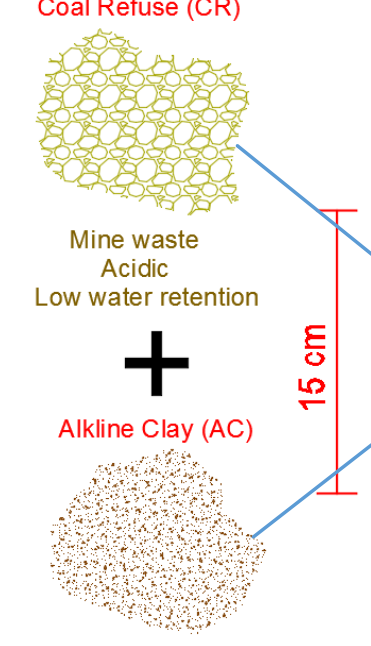

Aluminum industry waste
Basic High water retention
COLUMN EXPERIMENTS

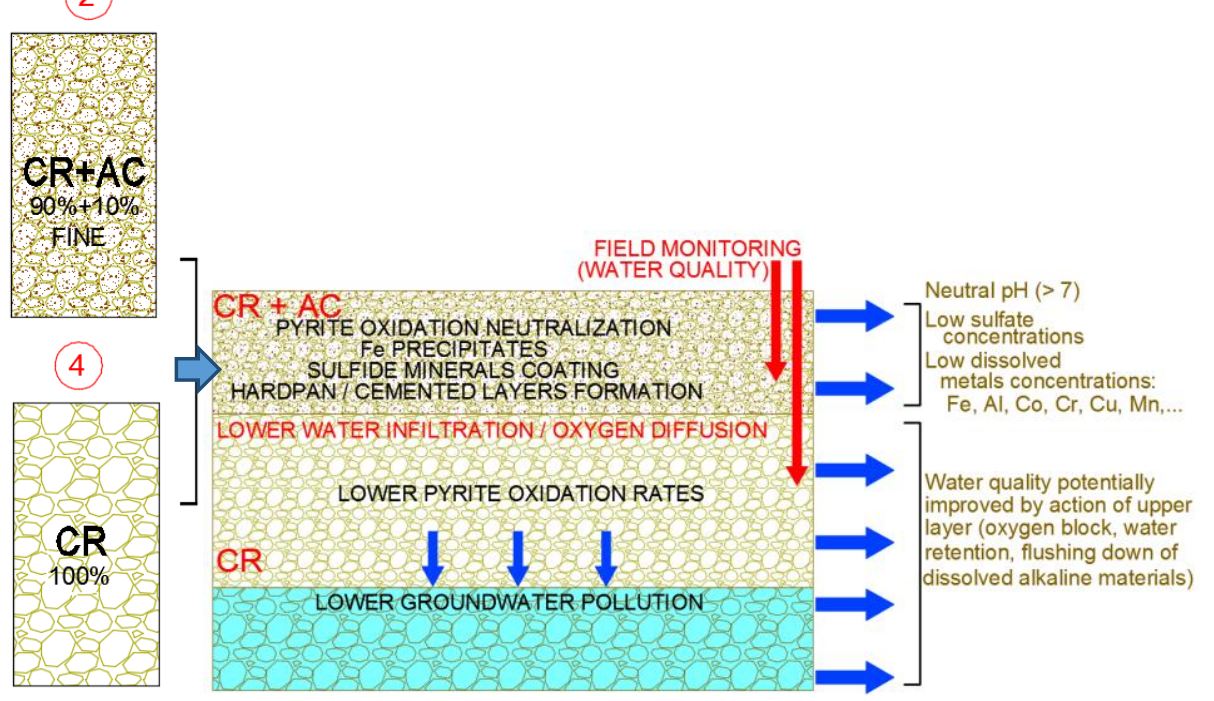

